\title{
Quantitative genetic analysis of agronomic and morphological traits in sorghum, Sorghum bicolor
}

\author{
Riyazaddin Mohammed ${ }^{1,2}$, Ashok K. Are ${ }^{1}$, Ramaiah Bhavanasi ${ }^{1}$, Rajendra S. Munghate ${ }^{1}$, \\ Polavarapu B. Kavi Kishor ${ }^{2}$ and Hari C. Sharma ${ }^{1 *}$ \\ ${ }^{1}$ International Crops Research Institute for the Semi-Arid Tropics, Patancheru, India, ${ }^{2}$ Department of Genetics, Osmania \\ University, Hyderabad, India
}

OPEN ACCESS

Edited by:

Scott Nicholas Johnson, University of Western Sydney, Australia

Reviewed by: Anil Khar,

Indian Agricultural Research Institute,

India

Hao Peng,

Washington State University, USA

*Correspondence:

Hari C. Sharma

h.sharma@cgiar.org

Specialty section:

This article was submitted to Crop Science and Horticulture,

a section of the journal

Frontiers in Plant Science

Received: 15 July 2015 Accepted: 17 October 2015 Published: 03 November 2015

Citation:

Mohammed R, Are AK, Bhavanasi R, Munghate RS, Kavi Kishor PB and Sharma HC (2015) Quantitative genetic analysis of agronomic and morphological traits in sorghum,

Sorghum bicolor.

Front. Plant Sci. 6:945. doi: 10.3389/fp/s.2015.00945
The productivity in sorghum is low, owing to various biotic and abiotic constraints. Combining insect resistance with desirable agronomic and morphological traits is important to increase sorghum productivity. Therefore, it is important to understand the variability for various agronomic traits, their heritabilities and nature of gene action to develop appropriate strategies for crop improvement. Therefore, a full diallel set of 10 parents and their 90 crosses including reciprocals were evaluated in replicated trials during the 2013-14 rainy and postrainy seasons. The crosses between the parents with early- and late-flowering flowered early, indicating dominance of earliness for anthesis in the test material used. Association between the shoot fly resistance, morphological, and agronomic traits suggested complex interactions between shoot fly resistance and morphological traits. Significance of the mean sum of squares for GCA (general combining ability) and SCA (specific combining ability) of all the studied traits suggested the importance of both additive and non-additive components in inheritance of these traits. The GCA/SCA, and the predictability ratios indicated predominance of additive gene effects for majority of the traits studied. High broad-sense and narrow-sense heritability estimates were observed for most of the morphological and agronomic traits. The significance of reciprocal combining ability effects for days to $50 \%$ flowering, plant height and 100 seed weight, suggested maternal effects for inheritance of these traits. Plant height and grain yield across seasons, days to 50\% flowering, inflorescence exsertion, and panicle shape in the postrainy season showed greater specific combining ability variance, indicating the predominance of non-additive type of gene action/epistatic interactions in controlling the expression of these traits. Additive gene action in the rainy season, and dominance in the postrainy season for days to $50 \%$ flowering and plant height suggested $G \times E$ interactions for these traits.

Keywords: sorghum, combining ability, heritability, agronomic traits, morphological traits, GCA, SCA, grain yield

\section{INTRODUCTION}

Sorghum [Sorghum bicolor (L.) Moench] is an important crop grown primarily in warm and dry climates with a wide range of adaptability to various agro-ecological conditions. It is the fifth most important food crop after wheat, rice, maize, and barley (FAO, 2004), and is widely grown in the semi-arid regions. It is the staple food for 600 million people living in the semi-arid regions. 
India is the third largest sorghum producer after Nigeria and United States of America, with 6.25 million hectares of area under sorghum cultivation, and with a total production of 5.98 million tonnes (FAOSTAT, 2012).

Information on inheritance of agronomic and morphological traits is useful for improving genotypic performance across environments. In sorghum, both the additive and non-additive type of gene action governs the inheritance of morphological and agronomic traits (Nimbalkar and Bapat, 1992; Umakanth et al., 2002; Mohammed Maarouf, 2009) with considerable amount of G X E interaction (Jayanthi et al., 1996; Dhillon et al., 2006; Aruna et al., 2011a).

Most of the morphological traits in sorghum are associated with one or more economically important traits, and will be helpful in selecting the high yielding sorghum genotypes. Brown midrib increases the fodder quality, while the presence of awns acts as a mechanical barrier to bird damage (Porter et al., 1978; Kullaiswamy and Goud, 1983). Genotypes with tancolored plants showed resistance to various fungal diseases while the genotypes with closed glumes are resistant to grain mold (Melake-Berhan et al., 1996; Murty, 2000).

Although, considerable progress has been made in identifying insect-resistant sorghums (Sharma, 1993; Sharma et al., 2003), but there is little progress in developing insect-resistant high yielding varieties for cultivation by the farmers. This is largely because of the lack of knowledge on inheritance of the agronomic and morphological characteristics associated with insect resistance and grain yield (Sharma et al., 2005; Riyazaddin et al., 2015). The combining ability analysis is useful to understand the nature of gene action, and has been used by the breeders to select the suitable parents for the crossing program. An understanding of the inheritance of morphological and agronomic traits will be helpful in combining the genes for insect resistance and desirable agronomic traits and grain characteristics to increase production and productivity of sorghum. Therefore, we developed a full diallel involving 10 parents to study the inheritance of morphological and agronomic traits. The combining ability studies will be helpful to identify genotypes which can be utilized in the hybridization.

\section{MATERIALS AND METHODS}

\section{Experimental Material}

Based on per se performance of sorghum genotypes in the field against shoot fly, Atherigona soccata and molecular diversity, 10 morphologically and genetically diverse sorghum genotypes (Annexure I in Supplementary Material) adapted to the rainy and postrainy seasons were selected and crossed in all possible combinations, which generated 45 direct crosses and 45 reciprocal crosses. These crosses along with the parents were evaluated in a randomized complete block design in three replications during the 2013-14 rainy and postrainy seasons at the International Crops Research Institute for the Semi-Arid Tropics (ICRISAT), Patancheru, Hyderabad, Telangana, India (latitude $17.53^{\circ} \mathrm{N}$, longitude $78.27^{\circ} \mathrm{E}$, and altitude of $545 \mathrm{~m}$ ).

Sowing of the test genotypes was carried out using a two cone planter. Each test plot consists of a row length of $2.0 \mathrm{~m}$ and a row to row spacing of $75 \mathrm{~cm}$. A distance of $10 \mathrm{~cm}$ was maintained in-between the plants within a row. Application of a basal dose of Ammonium phosphate to the field was carried out at $100 \mathrm{~kg} / \mathrm{ha}$. Each parent was sown in two rows, and a single row of $F_{1}$. Thinning of the test plots was carried out at 7 days after seedling emergence (DAE) and a plant population of 40 plants were retained in a test plot. At 30 DAE earthing up was carried out along with top dressing with urea at $100 \mathrm{~kg} / \mathrm{ha}$. During the postrainy season furrow irrigation was given to the experimental material. One set of the replicated test material was grown under protected conditions (application of carbofuran $3 \mathrm{G}$ granules in the leaf whorls at 7 days after seedling emergence, and cypermethrin spray after 5 days) to record the agronomic and morphological traits in the undamaged plants during the rainy and postrainy seasons.

\section{Observations}

\section{Agronomic Characteristics}

Data were recorded on days to $50 \%$ flowering, plant height, agronomic score, 100 seed weight, and grain yield. Days to $50 \%$ flowering was recorded when half of the panicles and nearly $50 \%$ of plants in the plot had attained the anthesis stage. Height of three plants was measured from the base of the plant to the tip of the panicle at physiological maturity in plants selected at random within a test plot. The agronomic desirability of the genotype was recorded at crop maturity on a $1-5$ scale $(1=$ high productive potential, and $5=$ poor productive potential). Data on 100 seed weight and grain yield/plot for parents, and grain yield/5 plants for $\mathrm{F}_{1} \mathrm{~s}$ were recorded after crop harvest.

\section{Morphological Characteristics}

Inflorescence exsertion was scored on a $1-4$ scale $(1=$ panicle fully exserted, and $4=$ panicle recurved); panicle compactness on a $1-3$ scale $(1=$ loose panicle, and $3=$ compact panicle); panicle shape on a $1-4$ scale $(1=$ erect panicle, and $4=$ elliptic panicle); glume coverage on a $1-9$ scale $(1=25 \%$ grain covered with glumes, and $9=$ glumes longer than the grain); awns on 1-2 scale ( $1=$ absence of awns, $2=$ presence of awns); grain luster on $1-2$ scale ( $1=$ non-lustrous grain, 2 = lustrous grain); and grain color on a $1-5$ scale $(1=$ white colored grain and $5=$ buff colored grain) (IBPGR and ICRISAT, 1993).

\section{Statistical Analysis}

Analysis of variance (ANOVA) was carried out using GenStat ${ }^{\circledR}$ 13th version (GenStat, 2010). F-test was used to test the significance differences between the genotypes, and least significance difference (LSD) for comparing the genotypic means at $P \leq 0.05$. Simple correlation coefficients were calculated to determine the association between the traits studied. Partitioning of the combining abilities (GCA and SCA) was done using the method 1 and model 1 of Griffing (1956), that provides the information on nature of parents, and the hybrid performance, using Windowstat (Indostat Services, 2004) software. The coefficient of variations at phenotypic and genotypic level variation was estimated using the formula adopted by Johnson et al. (1955) and predictability ratio using Baker (1978). 


\section{RESULTS}

\section{Agronomic Traits}

Evaluation of 10 parents and $90 \mathrm{~F}_{1}$ s, including the reciprocals, showed significant differences for all the traits studied across seasons at $P \leq 0.01$. Days to $50 \%$ flowering was ranged from 61 to 81 days in the rainy season, 56-78 days in the postrainy season (Table 1). Almost all the crosses flowered early, with few exceptions. Crosses between the parents with early- and late-flowering were early-flowering, indicating dominance of earliness for anthesis in the test material used. The crosses CSV 15 X ICSV 25019, CSV 15 X PS 35805, ICSV 25019 X CSV 15, ICSV 25019 X PS 35805, ICSV 25019 X IS 2123, ICSV 25019 X Swarna, PS 35805 X CSV 15, PS 35805 X ICSV 25019, PS 35805 X IS 2146, PS 35805 X Swarna, Swarna X ICSV 25019, and Swarna X PS 35805 exhibited moderate plant height across seasons. Parents and the crosses with moderate plant height can be exploited in developing the commercial hybrids amenable for mechanical harvesting.

Ten crosses exhibited high 100 seed weight and grain yield with good agronomic desirability. Grain yield of the crosses CSV 15 X IS 2123, ICSV 25019 X Swarna, PS 35805 X Swarna, IS 2123 X CSV 15, IS 2123 X ICSV 25019, IS 2123 X Swarna, Swarna X ICSV 25019, and Swarna X IS 2123 was high in the rainy season.

\section{Morphological and Grain Characteristics}

All the panicle traits showed significant variability among the genotypes for all the characteristics studied, in both the rainy and postrainy seasons with significant variance ratio $(P \leq 0.01)$ (Table 2). The mean scores for inflorescence exsertion were 1.90 and 2.41; for panicle compactness 2.30 and 2.63; and for glume coverage 2.00 and 1.71 , respectively, in the rainy and postrainy seasons.

\section{Association of the Agronomic and Morphological Traits with Shoot Fly Resistance}

Days to 50\% flowering, inflorescence exsertion, panicle compactness, glume coverage, and presence of awns were significantly and negatively correlated with shoot fly damage parameters across seasons, with few exceptions (Table 3). Plant height, 100 seed weight, and grain yield showed positive correlation with shoot fly damage across seasons.

\section{Association between the Agronomic Traits \\ Agronomic score was positively correlated with days to $50 \%$ flowering and plant height, but negatively correlated with grain yield (Table 4). Days to $50 \%$ flowering were significantly and positively correlated with plant height, and negatively correlated with 100 seed weight and grain yield. Grain yield was positively correlated with plant height in the postrainy season, and 100 seed weight across seasons. Significant positive correlation was observed between plant height and 100 seed weight in the postrainy season.}

\section{Association between the Morphological Traits}

Significant positive correlation was observed between inflorescence exsertion and panicle compactness, and between awns and the panicle traits across seasons (Table 5). Panicle shape was positively correlated with inflorescence exsertion, and panicle compactness in the postrainy season.

\section{Combining Ability Analysis}

Mean sum of squares for general combining ability of all the traits studied in the rainy season and postrainy seasons were significant at $P=0.01$ (Table 6). Mean sum of squares due to SCA was significant for all the traits studied, during the rainy and postrainy seasons, except grain luster during rainy season and agronomic score and waxy bloom in the postrainy season indicating the role of both additive and non-additive nature of gene action in controlling most of the morphological and agronomic traits. The mean sum of squares due to reciprocal crosses was significant for days to $50 \%$ flowering and 100 seed weight across seasons, inflorescence exsertion during the rainy season; and plant height, panicle compactness, and panicle shape during the postrainy season, suggesting the influence of cytoplasmic factors in the expression of these traits.

\section{Estimates of General Combining Ability (gca), Specific Combining Ability (sca) and Reciprocal Effects} gca Effects of Agronomic Traits

gca effects of days to $50 \%$ flowering ranged from -2.87 (Phule Anuradha) to 3.36 (ICSV 700) in the rainy season, and from -3.65 (CSV 15) to 4.40 (ICSV 700) in the postrainy season (Table 7). Phule Anuradha $\left(-2.87^{* *}\right)$, ICSV $25019\left(-1.85^{* *}\right)$, IS $2146\left(-0.77^{* *}\right)$ and Swarna $\left(-1.37^{* *}\right)$ exhibited significant negative gca effects in the rainy season, and Phule Anuradha $\left(-1.61^{* *}\right)$, CSV $15\left(-3.65^{* *}\right)$, ICSV $25019\left(-2.58^{* *}\right)$, PS 35805 $\left(-2.58^{* *}\right)$, and Swarna $\left(-2.60^{* *}\right)$ exhibited significant negative gca effects for days to $50 \%$ flowering in the postrainy season. ICSV $700\left(3.36^{* *}, 4.40^{* *}\right.$, respectively, in the rainy and postrainy season), M 35-1 $\left(0.50^{*}, 2.30^{* *}\right)$, IS $2123\left(1.33^{* *}, 1.70^{* *}\right)$, and IS $18551\left(2.46^{* *}, 3.17^{* *}\right)$ across seasons and IS $2146\left(1.44^{* *}\right)$ in the postrainy season showed significant positive gca effects for days to $50 \%$ flowering.

gca effects for plant height ranged from -44.49 (ICSV 25019) to 32.23 (ICSV 700) in the rainy season, -28.69 (ICSV 25019) to 20.59 (IS 18551) in the postrainy season. ICSV $25019\left(-44.49^{* *}\right.$ and $-28.69^{* *}$, respectively, in the rainy and postrainy seasons), PS $35805\left(-42.96^{* *}\right.$ and $\left.-27.69^{* *}\right)$ and Swarna $\left(-16.10^{* *}\right.$ and $-3.36^{* *}$ ) exhibited significant negative gca effects for plant height across seasons. ICSV 700, Phule Anuradha, M 35-1, CSV 15, IS 2123, IS 2146, and IS 18551 in the rainy season, and ICSV 700, Phule Anuradha, M 35-1, and IS 18551 in the postrainy season exhibited significant positive $g c a$ effects for plant height.

gca effects for 100 seed weight ranged from -0.31 (IS 18551) to 0.38 (Swarna) in the rainy and -0.43 (PS 35805) to 0.56 (Phule Anuradha) in the postrainy seasons. PS $35805\left(-0.07^{* *}\right)$, IS 2123 
TABLE 1 | Agronomic characteristics of sorghum genotypes (Parents and $\mathrm{F}_{1}$ 's) evaluated for resistance to sorghum shoot fly, $A$. soccata across seasons (ICRISAT, Patancheru, 2013-14).

\begin{tabular}{|c|c|c|c|c|c|c|c|c|c|c|}
\hline \multirow[t]{2}{*}{ Pedigree } & \multicolumn{2}{|c|}{ Days to $50 \%$ flowering } & \multicolumn{2}{|c|}{ Plant height (cm) } & \multicolumn{2}{|c|}{100 seed weight $(g)$} & \multicolumn{2}{|c|}{ Grain yield (t/ha) } & \multicolumn{2}{|c|}{ Agronomic score } \\
\hline & 2013 R & 2013 PR & 2013 R & 2013 PR & 2013 R & 2013 PR & 2013 R & 2013 PR & 2013 R & 2013 PR \\
\hline \multicolumn{11}{|l|}{ PARENTS } \\
\hline ICSV 700 & 81 & 77 & 309 & 189 & 2.30 & 2.37 & 0.79 & 5.02 & 5.00 & 3.67 \\
\hline Phule Anuradha & 62 & 63 & 259 & 179 & 2.90 & 4.23 & 1.22 & 6.51 & 4.67 & 4.33 \\
\hline M 35-1 & 75 & 72 & 306 & 187 & 2.40 & 3.50 & 0.66 & 6.87 & 5.00 & 3.67 \\
\hline CSV 15 & 71 & 61 & 254 & 180 & 2.50 & 3.03 & 1.54 & 5.23 & 3.00 & 3.00 \\
\hline ICSV 25019 & 65 & 64 & 131 & 109 & 2.30 & 2.10 & 1.90 & 3.01 & 2.00 & 3.00 \\
\hline PS 35805 & 69 & 65 & 121 & 102 & 2.20 & 2.37 & 1.70 & 3.12 & 2.00 & 3.00 \\
\hline IS 2123 & 73 & 72 & 283 & 176 & 2.13 & 2.50 & 0.77 & 5.64 & 5.00 & 4.33 \\
\hline IS 2146 & 68 & 73 & 279 & 181 & 1.80 & 2.33 & 0.88 & 5.56 & 5.00 & 4.67 \\
\hline IS 18551 & 78 & 78 & 313 & 203 & 1.70 & 2.23 & 0.51 & 4.23 & 5.00 & 3.33 \\
\hline Swarna & 67 & 63 & 166 & 138 & 3.30 & 3.77 & 1.89 & 5.17 & 2.00 & 2.00 \\
\hline \multicolumn{11}{|l|}{ DIRECT CROSSES } \\
\hline ICSV 700 X Phule Anuradha & 65 & 75 & 314 & 236 & 2.73 & 3.77 & 3.58 & 15.18 & 4.33 & 2.67 \\
\hline ICSV 700 XM 35-1 & 65 & 70 & 321 & 218 & 2.63 & 4.00 & 3.73 & 12.51 & 3.67 & 3.33 \\
\hline ICSV $700 \times$ CSV 15 & 75 & 71 & 327 & 209 & 2.37 & 3.30 & 4.73 & 14.18 & 2.33 & 4.00 \\
\hline ICSV 700 X ICSV 25019 & 67 & 68 & 308 & 199 & 2.80 & 3.63 & 4.80 & 12.72 & 3.00 & 3.00 \\
\hline ICSV 700 X PS 35805 & 67 & 67 & 309 & 204 & 2.47 & 3.07 & 6.25 & 12.13 & 3.33 & 3.67 \\
\hline ICSV 700 X IS 2123 & 68 & 69 & 303 & 219 & 2.50 & 3.40 & 4.12 & 13.73 & 4.67 & 4.33 \\
\hline ICSV 700 X IS 2146 & 69 & 71 & 318 & 208 & 2.53 & 3.53 & 2.57 & 5.49 & 4.00 & 3.67 \\
\hline ICSV 700 X IS 18551 & 67 & 70 & 339 & 231 & 2.40 & 3.30 & 5.31 & 11.87 & 3.67 & 3.33 \\
\hline ICSV 700 X Swarna & 67 & 68 & 319 & 213 & 3.07 & 4.03 & 4.10 & 10.46 & 5.00 & 3.00 \\
\hline Phule Anuradha XM 35-1 & 64 & 66 & 273 & 202 & 2.60 & 4.37 & 2.93 & 11.99 & 4.00 & 3.33 \\
\hline Phule Anuradha X CSV 15 & 62 & 59 & 302 & 202 & 3.00 & 4.07 & 1.97 & 8.94 & 4.00 & 3.33 \\
\hline Phule Anuradha X ICSV 25019 & 61 & 60 & 280 & 183 & 2.87 & 3.97 & 2.58 & 10.69 & 3.67 & 2.67 \\
\hline Phule Anuradha X PS 35805 & 62 & 61 & 280 & 177 & 2.97 & 3.53 & 5.89 & 14.08 & 3.33 & 3.33 \\
\hline Phule Anuradha X IS 2123 & 63 & 64 & 280 & 188 & 2.60 & 3.83 & 3.40 & 12.40 & 4.33 & 4.00 \\
\hline Phule Anuradha X IS 2146 & 64 & 66 & 292 & 187 & 2.20 & 4.00 & 2.89 & 7.17 & 4.00 & 3.67 \\
\hline Phule Anuradha X IS 18551 & 65 & 65 & 310 & 208 & 2.27 & 3.47 & 4.68 & 12.70 & 3.33 & 4.00 \\
\hline Phule Anuradha X Swarna & 63 & 62 & 297 & 199 & 3.43 & 4.33 & 4.76 & 9.44 & 3.33 & 3.33 \\
\hline M 35-1 X CSV 15 & 64 & 70 & 317 & 211 & 2.97 & 3.37 & 4.47 & 11.58 & 3.67 & 3.00 \\
\hline M 35-1 X ICSV 25019 & 63 & 63 & 304 & 203 & 2.77 & 3.83 & 3.34 & 13.94 & 3.33 & 3.33 \\
\hline M 35-1 X PS 35805 & 63 & 64 & 296 & 171 & 2.73 & 3.43 & 4.00 & 11.51 & 2.67 & 3.00 \\
\hline M 35-1 X IS 2123 & 66 & 70 & 296 & 198 & 2.57 & 3.50 & 3.84 & 14.34 & 4.67 & 4.33 \\
\hline M 35-1 X IS 2146 & 64 & 69 & 293 & 198 & 2.20 & 3.93 & 1.96 & 7.17 & 4.67 & 4.00 \\
\hline M 35-1 X IS 18551 & 67 & 70 & 322 & 211 & 2.37 & 3.17 & 4.69 & 14.47 & 3.67 & 3.00 \\
\hline M 35-1 X Swarna & 69 & 67 & 314 & 208 & 2.37 & 3.13 & 4.49 & 11.56 & 3.33 & 3.33 \\
\hline CSV 15 X ICSV 25019 & 63 & 56 & 229 & 149 & 2.47 & 3.50 & 6.94 & 13.28 & 1.67 & 2.33 \\
\hline CSV 15 X PS 35805 & 65 & 57 & 250 & 158 & 2.50 & 3.33 & 7.16 & 12.62 & 2.00 & 2.67 \\
\hline CSV 15 X IS 2123 & 66 & 61 & 298 & 184 & 2.67 & 3.23 & 7.95 & 14.49 & 4.33 & 3.67 \\
\hline CSV 15 X IS 2146 & 64 & 63 & 290 & 197 & 2.77 & 3.30 & 2.88 & 7.34 & 3.33 & 3.67 \\
\hline CSV 15 X IS 18551 & 65 & 63 & 340 & 214 & 2.47 & 2.97 & 5.72 & 13.77 & 3.00 & 3.00 \\
\hline CSV 15 X Swarna & 65 & 59 & 308 & 198 & 3.10 & 3.67 & 4.38 & 11.11 & 3.67 & 2.33 \\
\hline ICSV 25019 X PS 35805 & 66 & 60 & 127 & 104 & 1.97 & 2.43 & 4.33 & 7.57 & 2.00 & 3.00 \\
\hline ICSV 25019 X IS 2123 & 64 & 63 & 258 & 167 & 2.87 & 3.50 & 4.95 & 13.61 & 4.67 & 3.33 \\
\hline ICSV 25019 X IS 2146 & 63 & 64 & 273 & 173 & 2.80 & 3.70 & 2.41 & 6.99 & 4.33 & 3.67 \\
\hline ICSV 25019 X IS 18551 & 65 & 65 & 302 & 209 & 2.37 & 2.90 & 4.18 & 12.91 & 3.33 & 2.67 \\
\hline ICSV 25019 X Swarna & 61 & 62 & 187 & 140 & 3.27 & 3.00 & 7.65 & 10.16 & 1.67 & 2.67 \\
\hline
\end{tabular}


TABLE 1 | Continued

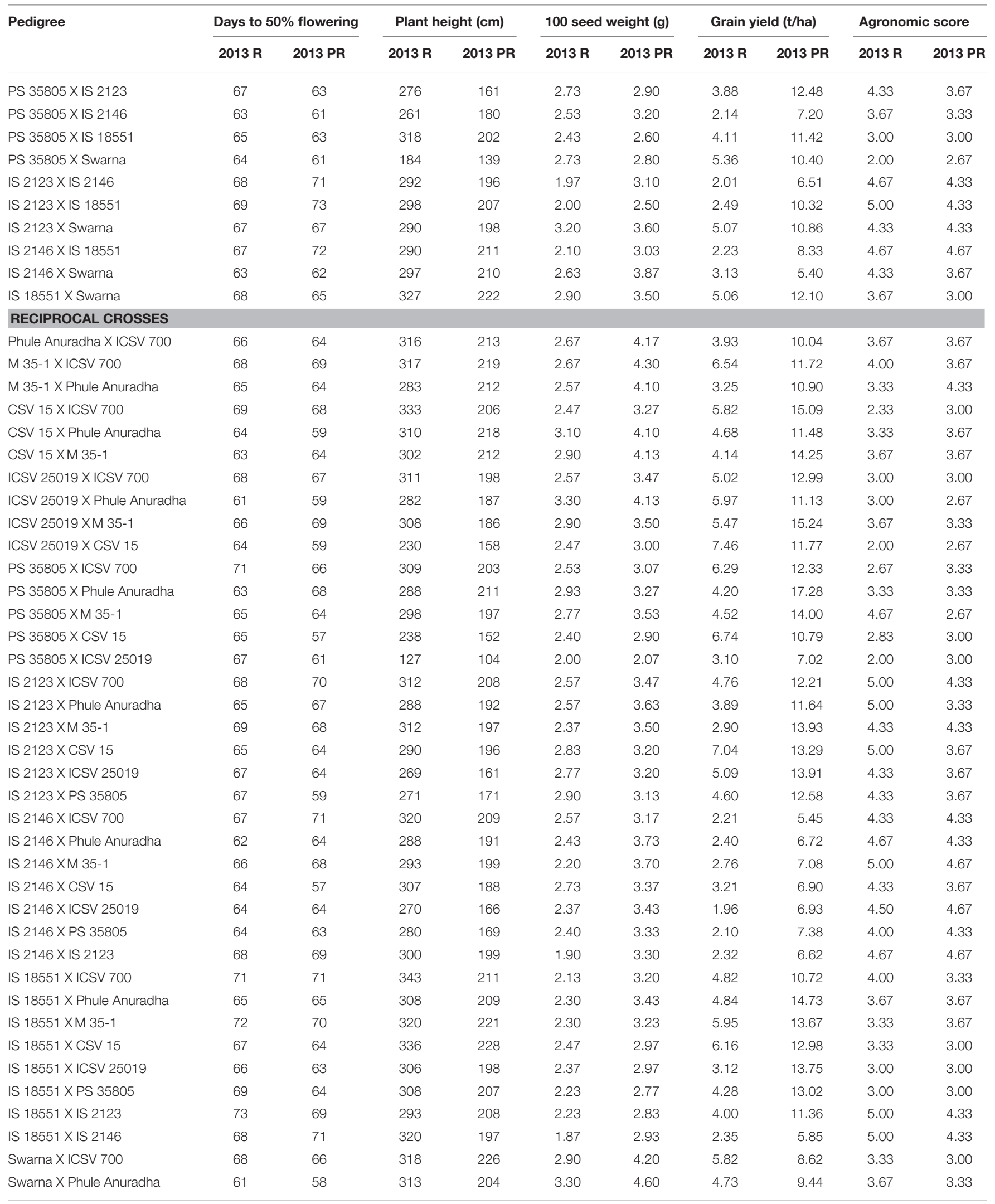


TABLE 1 | Continued

\begin{tabular}{|c|c|c|c|c|c|c|c|c|c|c|}
\hline \multirow[t]{2}{*}{ Pedigree } & \multicolumn{2}{|c|}{ Days to $50 \%$ flowering } & \multicolumn{2}{|c|}{ Plant height (cm) } & \multicolumn{2}{|c|}{100 seed weight $(g)$} & \multicolumn{2}{|c|}{ Grain yield (t/ha) } & \multicolumn{2}{|c|}{ Agronomic score } \\
\hline & 2013 R & 2013 PR & 2013 R & 2013 PR & 2013 R & 2013 PR & 2013 R & 2013 PR & 2013 R & 2013 PR \\
\hline Swarna XM 35-1 & 64 & 62 & 316 & 193 & 3.13 & 4.47 & 4.36 & 10.39 & 3.33 & 3.00 \\
\hline Swarna X CSV 15 & 63 & 57 & 299 & 217 & 2.77 & 4.10 & 4.92 & 11.58 & 3.67 & 2.67 \\
\hline Swarna X ICSV 25019 & 61 & 59 & 187 & 142 & 2.83 & 2.90 & 7.38 & 9.46 & 2.00 & 2.67 \\
\hline Swarna X PS 35805 & 65 & 62 & 191 & 149 & 2.57 & 3.03 & 8.70 & 9.10 & 1.67 & 2.33 \\
\hline Swarna X IS 2123 & 64 & 63 & 294 & 177 & 2.90 & 3.73 & 4.94 & 10.79 & 4.33 & 4.00 \\
\hline Swarna X IS 2146 & 63 & 60 & 287 & 211 & 2.60 & 3.50 & 2.36 & 5.92 & 3.33 & 3.33 \\
\hline Swarna X IS 18551 & 65 & 67 & 330 & 230 & 2.83 & 3.40 & 5.27 & 11.69 & 3.67 & 3.00 \\
\hline Mean & 66 & 65 & 286 & 191 & 2.60 & 3.38 & 4.10 & 10.43 & 3.69 & 3.46 \\
\hline $\mathrm{SE} \pm$ & 1.13 & 1.40 & 6.21 & 5.83 & 0.12 & 0.15 & 0.71 & 1.04 & 0.35 & 0.40 \\
\hline $\operatorname{Vr}(99,198)$ & $10.09^{\star *}$ & $10.90^{\star \star}$ & $56.80^{\star \star}$ & $22.91^{\star *}$ & $8.66^{\star \star}$ & $12.87^{\star \star}$ & $6.37^{\star \star}$ & $9.65^{\star \star}$ & $7.48^{\star \star}$ & $2.41^{\star \star}$ \\
\hline LSD (P 0.05) & 3.14 & 3.90 & 17.33 & 16.26 & 0.34 & 0.42 & 1.97 & 2.90 & 0.97 & 1.12 \\
\hline
\end{tabular}

${ }^{\star \star} F$ probability significant at $P 0.01 ; R$, rainy season; $P R$, postrainy season.

$\left(-0.06^{* *}\right)$, IS $2146\left(-0.26^{* *}\right)$, and IS $18551\left(-0.31^{* *}\right)$ in the rainy season, and ICSV $25019\left(-0.22^{* *}\right)$, PS $35805\left(-0.43^{* *}\right)$, IS $2123\left(-0.16^{* *}\right)$, and IS $18551\left(-0.40^{* *}\right)$ in the postrainy season exhibited significant negative $\mathrm{gca}$ effects for 100 seed weight. Whereas, the genotypes Phule Anuradha (0.20**), CSV $15\left(0.09^{* *}\right)$, and Swarna $\left(0.38^{* *}\right)$ in the rainy season, and ICSV $700\left(0.07^{*}\right)$, Phule Anuradha $\left(0.56^{* *}\right)$, M 35-1 (0.33**), and Swarna $\left(0.29^{* *}\right)$ in the postrainy season showed positive $g c a$ effects for 100 seed weight.

gca effects of sorghum grain yield ranged from -1.79 (IS 2146) to 0.90 (CSV 15) in the rainy season, and -3.86 (IS 2146) to 1.27 (M 35-1) in the postrainy season. The gca effects of Phule Anuradha $\left(-0.43^{* *}\right)$, M $35-1\left(-0.34^{*}\right)$, and IS $2146\left(-1.79^{* *}\right)$ in the rainy season, and IS $2146\left(-3.86^{* *}\right)$ and Swarna $\left(-0.99^{* *}\right)$ in the postrainy season exhibited significant negative $g c a$ effects for grain yield. The genotypes CSV $15\left(0.90^{* *}\right)$, ICSV 25019 $\left(0.40^{* *}\right)$, PS $35805\left(0.48^{* *}\right)$, and Swarna $\left(0.74^{* *}\right)$ in the rainy season and ICSV $700\left(0.44^{*}\right)$, Phule Anuradha $\left(0.52^{*}\right)$, M 35-1 $\left(1.27^{* *}\right)$, CSV $15\left(0.86^{* *}\right)$, IS $2123\left(0.89^{* *}\right)$, and IS $18551\left(0.77^{* *}\right)$ in the postrainy season showed significant positive gca effects for grain yield. $g c a$ effects of agronomic score ranged from -0.75 (PS 35805 ) to 0.96 (IS 2123) in the rainy season, and -0.48 (Swarna) to 0.66 (IS 2146) in the postrainy season.

\section{gca Effects of Morphological Traits}

The gca effects of inflorescence exsertion ranged from -0.63 (Swarna) to 0.57 (IS 2123) in the rainy season, and -1.06 (Swarna) to 1.51 (IS 2123) in the postrainy season (Table 7). gca effects of panicle compactness ranged from -0.25 (Swarna) to 0.62 (IS 2123) in the rainy season, and -0.50 (CSV 15) to 0.37 (IS 2123 and IS 2146) in the postrainy season. Six genotypes exhibited significant and negative gca effects and two genotypes exhibited positive and significant gca effects for panicle compactness in the rainy season. Three genotypes exhibited significant negative $g c a$ effects, while five genotypes exhibited significant positive $g c a$ effects for panicle compactness in the postrainy season. $g c a$ effects of the panicle shape ranged from -0.94 (Swarna) to 0.58 (IS 2146) in the postrainy season. The general combining ability of glume cover ranged from -0.65 to 2.52 in the rainy season, and -0.51 to 2.89 in the postrainy season. All the genotypes exhibited significant negative $g c a$ effects except IS $18551\left(2.52^{* *}\right.$ and $\left.2.89^{* *}\right)$ with significant positive $g c a$ effects for glume coverage across seasons. gca effects of awns ranged from -0.36 to 0.25 in the rainy season, and -0.35 to 0.25 in the postrainy season. CSV 15, ICSV 25019, PS 35805, and Swarna exhibited significant negative gca effects, while ICSV 700, Phule Anuradha, M 35-1, IS 2123, IS 2146, and IS 18551 exhibited significant positive $g c a$ effects for presence of awns across seasons.

\section{Specific Combining Ability (sca) Effects sca effects of agronomic traits}

The sca effects for days to $50 \%$ flowering ranged from -3.66 to 3.19 and -3.20 to 3.61 during the rainy and postrainy season, respectively. For plant height the sca effects ranged from -71.09 to 45.68 and -30.09 to 22.75 , for 100 seed weight from -0.56 to 0.37 and -0.50 to 0.38 , for grain yield from -1.24 to 2.65 and -3.24 to 4.70 , respectively, in the rainy and postrainy seasons. For agronomic score from -1.02 to 0.91 in the rainy season (Table 8). Ten hybrids in the rainy season and nine hybrids in the postrainy season exhibited significant negative sca effects for days to $50 \%$ flowering. ICSV $700 \mathrm{X}$ CSV 15 across seasons, and Phule Anuradha X PS 35805, M 35-1 X CSV 15 in the postrainy season showed significant positive sca effects for days to $50 \%$ flowering.

Significant negative $s c a$ effects for plant height were observed for 14 hybrids in the rainy season, and 10 hybrids in the postrainy season. Fifteen hybrids across seasons, Phule Anuradha X Swarna, ICSV 25019 X IS 2123, ICSV 25019 X IS 2146, PS 35805 X IS 2123, IS 2123 X Swarna in the rainy season, and M 35 $1 \mathrm{X}$ CSV 15 in the postrainy season exhibited significant positive sca effects for plant height.

Significant negative sca effects for grain yield were observed in Phule Anuradha X CSV 15, ICSV 25019 X PS 35805 across seasons, CSV $15 \mathrm{X}$ Swarna in the rainy season, and ICSV 700 
TABLE 2 | Panicle and grain characteristics of sorghum genotypes (Parents and $\mathrm{F}_{1}$ 's) evaluated for resistance to sorghum shoot fly, A. soccata across seasons (ICRISAT, Patancheru, 2013-14).

\begin{tabular}{|c|c|c|c|c|c|c|c|c|c|c|}
\hline \multirow[t]{2}{*}{ Pedigree } & \multicolumn{2}{|c|}{ Inflorescence exsertion } & \multicolumn{2}{|c|}{ Panicle compactness } & \multirow{2}{*}{$\frac{\text { Panicle shape }}{2013 \text { PR }}$} & \multicolumn{2}{|c|}{ Glume coverage } & \multicolumn{2}{|c|}{ Awns } & \multirow{2}{*}{$\frac{\text { Grain luster }}{2013 \text { PR }}$} \\
\hline & 2013 R & 2013 PR & 2013 R & 2013 PR & & 2013 R & 2013 PR & 2013 R & 2013 PR & \\
\hline \multicolumn{11}{|l|}{ PARENTS } \\
\hline ICSV 700 & 2.00 & 2.00 & 2.00 & 3.00 & 4.00 & 5.00 & 5.00 & 2.00 & 2.00 & 2.00 \\
\hline Phule Anuradha & 2.33 & 3.00 & 2.00 & 3.00 & 4.00 & 3.00 & 1.00 & 2.00 & 2.00 & 2.00 \\
\hline M 35-1 & 2.00 & 2.00 & 2.00 & 3.00 & 4.00 & 3.00 & 1.00 & 2.00 & 2.00 & 2.00 \\
\hline CSV 15 & 2.00 & 1.00 & 2.00 & 2.00 & 2.00 & 1.00 & 1.00 & 1.00 & 1.00 & 2.00 \\
\hline ICSV 25019 & 2.67 & 2.00 & 3.00 & 3.00 & 4.00 & 1.00 & 1.00 & 1.00 & 1.00 & 2.00 \\
\hline PS 35805 & 3.00 & 2.00 & 3.00 & 3.00 & 4.00 & 1.00 & 1.00 & 1.00 & 1.00 & 2.00 \\
\hline IS 2123 & 2.33 & 4.00 & 3.00 & 3.00 & 3.00 & 3.00 & 1.00 & 2.00 & 2.00 & 2.00 \\
\hline IS 2146 & 2.00 & 4.00 & 3.00 & 3.00 & 3.00 & 3.00 & 1.00 & 2.00 & 2.00 & 2.00 \\
\hline IS 18551 & 2.00 & 2.00 & 2.00 & 3.00 & 4.00 & 9.00 & 9.00 & 2.00 & 2.00 & 1.00 \\
\hline Swarna & 1.00 & 1.00 & 2.00 & 2.00 & 1.00 & 1.00 & 1.00 & 1.00 & 1.00 & 2.00 \\
\hline \multicolumn{11}{|l|}{ DIRECT CROSSES } \\
\hline ICSV 700 x Phule Anuradha & 2.00 & 2.67 & 2.00 & 3.00 & 4.00 & 1.67 & 1.00 & 2.00 & 2.00 & 2.00 \\
\hline ICSV 700 xM 35-1 & 2.00 & 2.33 & 2.00 & 3.00 & 4.00 & 1.67 & 1.00 & 2.00 & 2.00 & 2.00 \\
\hline ICSV 700 x CSV 15 & 1.67 & 1.33 & 2.00 & 2.00 & 1.33 & 1.00 & 1.00 & 1.00 & 1.00 & 2.00 \\
\hline ICSV 700 x ICSV 25019 & 2.00 & 1.67 & 2.00 & 2.33 & 2.00 & 1.00 & 1.00 & 1.00 & 1.00 & 2.00 \\
\hline ICSV 700 x PS 35805 & 2.00 & 1.00 & 2.00 & 3.00 & 4.00 & 1.67 & 1.00 & 1.00 & 1.00 & 2.00 \\
\hline ICSV 700 x IS 2123 & 2.00 & 4.00 & 3.00 & 3.00 & 3.00 & 1.67 & 1.00 & 2.00 & 2.00 & 2.00 \\
\hline ICSV 700 x IS 2146 & 2.00 & 3.00 & 2.67 & 3.00 & 3.33 & 2.33 & 1.00 & 2.00 & 2.00 & 2.00 \\
\hline ICSV 700 x IS 18551 & 1.33 & 2.33 & 2.00 & 3.00 & 4.00 & 5.67 & 4.33 & 2.00 & 2.00 & 1.67 \\
\hline ICSV 700 x Swarna & 2.00 & 1.00 & 2.00 & 2.00 & 1.00 & 1.67 & 1.67 & 1.00 & 1.00 & 2.00 \\
\hline Phule Anuradha x M 35-1 & 2.00 & 3.00 & 2.00 & 2.67 & 3.00 & 1.00 & 1.00 & 2.00 & 2.00 & 2.00 \\
\hline Phule Anuradha x CSV 15 & 1.67 & 1.67 & 2.00 & 2.00 & 1.33 & 1.00 & 1.00 & 1.00 & 1.00 & 2.00 \\
\hline Phule Anuradha x ICSV 25019 & 2.00 & 2.33 & 2.00 & 2.00 & 1.00 & 1.00 & 1.00 & 1.00 & 1.00 & 2.00 \\
\hline Phule Anuradha x PS 35805 & 2.00 & 3.00 & 2.33 & 2.33 & 2.00 & 1.00 & 1.00 & 1.00 & 1.00 & 2.00 \\
\hline Phule Anuradha x IS 2123 & 2.67 & 4.00 & 3.00 & 3.00 & 3.00 & 1.67 & 1.00 & 2.00 & 2.00 & 2.00 \\
\hline Phule Anuradha x IS 2146 & 2.67 & 4.00 & 2.67 & 3.00 & 3.00 & 1.67 & 1.00 & 2.00 & 2.00 & 2.00 \\
\hline Phule Anuradha x IS 18551 & 2.00 & 2.33 & 2.00 & 3.00 & 4.00 & 3.00 & 5.00 & 2.00 & 2.00 & 2.00 \\
\hline Phule Anuradha x Swarna & 1.67 & 1.33 & 2.00 & 2.00 & 1.00 & 1.00 & 1.00 & 1.00 & 1.00 & 2.00 \\
\hline M 35-1 x CSV 15 & 1.00 & 1.00 & 2.00 & 2.33 & 2.67 & 1.00 & 1.67 & 1.00 & 1.00 & 2.00 \\
\hline M 35-1 x ICSV 25019 & 1.00 & 1.00 & 2.00 & 2.00 & 1.00 & 1.00 & 1.00 & 1.00 & 1.00 & 2.00 \\
\hline M 35-1 x PS 35805 & 1.00 & 1.67 & 2.33 & 3.00 & 4.00 & 2.33 & 1.00 & 1.00 & 1.00 & 2.00 \\
\hline M 35-1 x IS 2123 & 2.00 & 4.00 & 2.67 & 3.00 & 3.00 & 1.67 & 1.00 & 2.00 & 2.00 & 2.00 \\
\hline M 35-1 x IS 2146 & 2.33 & 4.00 & 2.67 & 3.00 & 3.00 & 1.00 & 1.00 & 2.00 & 2.00 & 2.00 \\
\hline M 35-1 x IS 18551 & 1.67 & 2.33 & 2.00 & 3.00 & 4.00 & 5.00 & 4.33 & 2.00 & 2.00 & 2.00 \\
\hline M 35-1 x Swarna & 2.00 & 1.33 & 2.00 & 3.00 & 4.00 & 3.00 & 1.00 & 1.00 & 1.00 & 2.00 \\
\hline CSV 15 x ICSV 25019 & 2.33 & 3.00 & 2.00 & 2.00 & 1.33 & 1.00 & 1.00 & 1.00 & 1.00 & 2.00 \\
\hline CSV 15 x PS 35805 & 2.33 & 1.67 & 2.00 & 2.00 & 1.33 & 1.00 & 1.00 & 1.00 & 1.00 & 2.00 \\
\hline CSV 15 x IS 2123 & 2.00 & 4.00 & 3.00 & 3.00 & 3.33 & 1.67 & 1.00 & 1.00 & 1.00 & 2.00 \\
\hline CSV 15 x IS 2146 & 2.00 & 2.33 & 2.67 & 3.00 & 3.67 & 1.00 & 1.00 & 1.00 & 1.00 & 2.00 \\
\hline CSV 15 x IS 18551 & 1.33 & 1.33 & 2.00 & 2.00 & 1.00 & 4.33 & 3.67 & 1.33 & 1.00 & 2.00 \\
\hline CSV 15 x Swarna & 1.00 & 1.00 & 2.00 & 1.00 & 2.00 & 1.67 & 1.00 & 1.00 & 1.00 & 2.00 \\
\hline ICSV 25019 x PS 35805 & 3.00 & 3.00 & 2.33 & 3.00 & 4.00 & 1.00 & 1.00 & 1.00 & 1.00 & 2.00 \\
\hline ICSV 25019 x IS 2123 & 3.00 & 4.00 & 3.00 & 3.00 & 3.00 & 1.00 & 1.00 & 1.00 & 1.00 & 2.00 \\
\hline ICSV 25019 x IS 2146 & 2.33 & 4.00 & 2.67 & 3.00 & 3.67 & 1.00 & 1.00 & 1.00 & 1.00 & 2.00 \\
\hline ICSV 25019 x IS 18551 & 1.00 & 1.00 & 2.00 & 2.67 & 3.00 & 3.00 & 3.00 & 1.00 & 1.00 & 2.00 \\
\hline ICSV 25019 x Swarna & 1.00 & 1.33 & 2.00 & 2.00 & 1.00 & 1.00 & 1.00 & 1.00 & 1.00 & 2.00 \\
\hline PS 35805 x IS 2123 & 2.33 & 4.00 & 3.00 & 3.00 & 3.00 & 2.33 & 1.00 & 1.00 & 1.00 & 2.00 \\
\hline
\end{tabular}


TABLE 2 | Continued

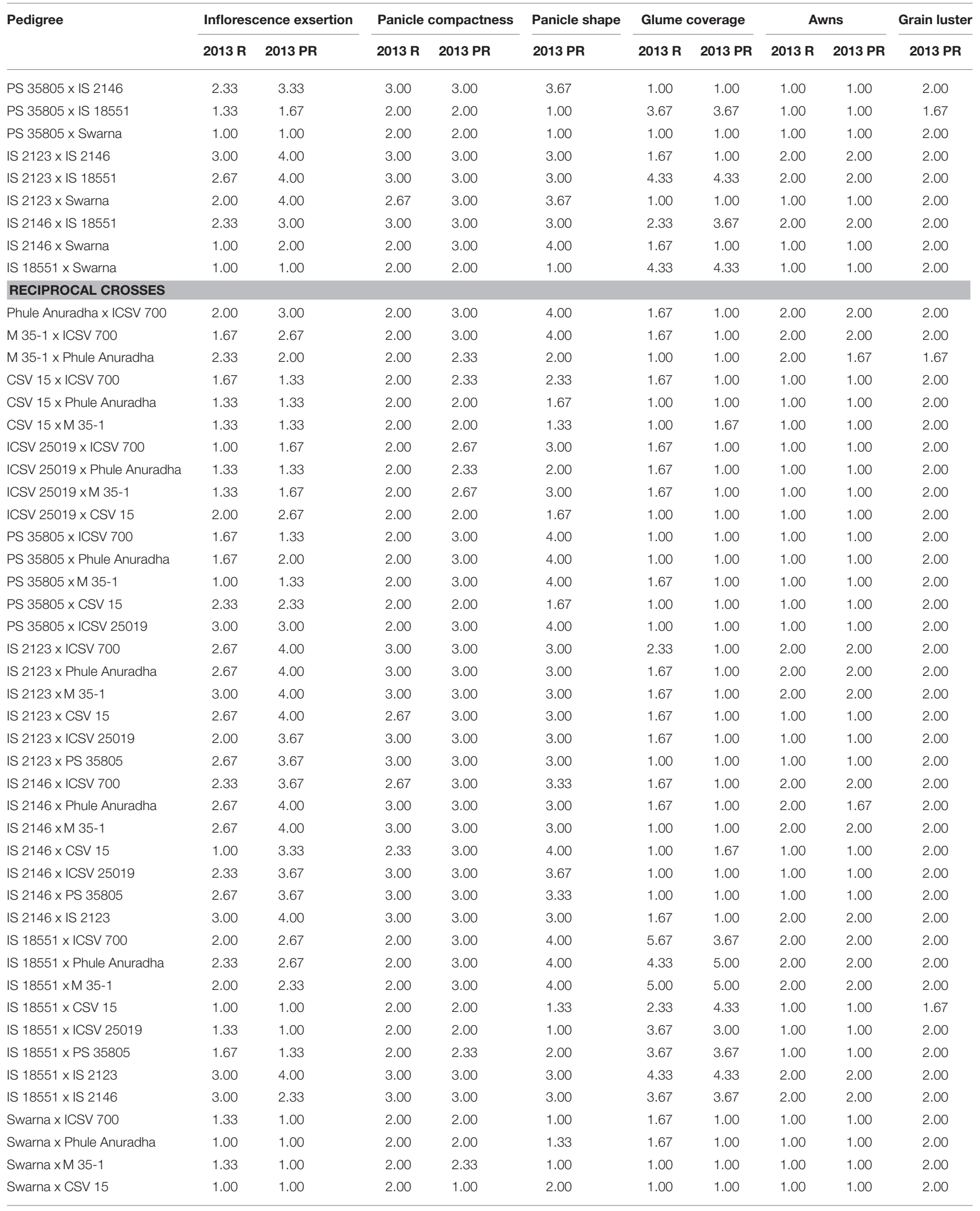


TABLE 2 | Continued

\begin{tabular}{|c|c|c|c|c|c|c|c|c|c|c|}
\hline \multirow[t]{2}{*}{ Pedigree } & \multicolumn{2}{|c|}{ Inflorescence exsertion } & \multicolumn{2}{|c|}{ Panicle compactness } & \multirow{2}{*}{$\begin{array}{l}\text { Panicle shape } \\
2013 \text { PR }\end{array}$} & \multicolumn{2}{|c|}{ Glume coverage } & \multicolumn{2}{|c|}{ Awns } & \multirow{2}{*}{$\frac{\text { Grain luster }}{2013 \text { PR }}$} \\
\hline & 2013 R & 2013 PR & 2013 R & 2013 PR & & 2013 R & 2013 PR & 2013 R & 2013 PR & \\
\hline Swarna x ICSV 25019 & 1.00 & 1.00 & 2.00 & 2.00 & 1.00 & 1.00 & 1.00 & 1.00 & 1.00 & 2.00 \\
\hline Swarna x PS 35805 & 1.00 & 1.00 & 2.00 & 2.00 & 1.00 & 1.00 & 1.00 & 1.00 & 1.00 & 2.00 \\
\hline Swarna x IS 2123 & 1.67 & 3.00 & 3.00 & 3.00 & 3.33 & 1.00 & 1.00 & 1.00 & 1.00 & 2.00 \\
\hline Swarna x IS 2146 & 1.67 & 1.00 & 2.00 & 3.00 & 4.00 & 1.67 & 1.00 & 1.00 & 1.00 & 2.00 \\
\hline Swarna x IS 18551 & 1.00 & 1.00 & 2.00 & 2.00 & 1.00 & 4.33 & 5.00 & 1.00 & 1.00 & 2.00 \\
\hline Mean & 1.90 & 2.41 & 2.30 & 2.63 & 2.75 & 2.00 & 1.71 & 1.40 & 1.35 & 1.98 \\
\hline $\mathrm{SE} \pm$ & 0.25 & 0.29 & 0.12 & 0.12 & 0.35 & 0.43 & 0.33 & 0.03 & 0.05 & 0.07 \\
\hline $\mathrm{Vr}$ & $6.49^{* \star}$ & $15.17^{\star \star}$ & $13.65^{\star \star}$ & $18.62^{\star *}$ & $9.81^{\star *}$ & $10.81^{\star *}$ & $19.91^{\star *}$ & $208.27^{\star *}$ & $102.88^{\star \star}$ & $3.18^{\star \star}$ \\
\hline LSD (P 0.05) & 0.69 & 0.81 & 0.33 & 0.32 & 0.99 & 1.20 & 0.92 & 0.09 & 0.13 & 0.19 \\
\hline
\end{tabular}

${ }^{\star \star} F$ probability significant at $P$ 0.05; $R$, rainy season; $P R$, postrainy season.

TABLE 3 | Association of agronomic and panicle traits with expression of resistance to sorghum shoot fly, Atherigona soccata (ICRISAT, Patancheru, 2013-14).

\begin{tabular}{|c|c|c|c|c|}
\hline Traits & $\begin{array}{l}\text { Plants with shoot } \\
\text { fly eggs (\%) }\end{array}$ & $\begin{array}{l}\text { Number of shoot } \\
\text { fly eggs/plant }\end{array}$ & $\begin{array}{c}\text { Shoot fly } \\
\text { deadhearts (\%) }\end{array}$ & ORS \\
\hline Days to $50 \%$ flowering & $-0.20^{*}\left(-0.41^{\star \star}\right)$ & $0.13(-0.07)$ & $-0.31^{\star \star}\left(-0.47^{\star \star}\right)$ & $0.09\left(-0.24^{\star \star}\right)$ \\
\hline 100 seed weight & $0.21^{*}\left(0.28^{* *}\right)$ & $-0.03(-0.04)$ & $0.39^{\star \star}\left(0.32^{\star \star}\right)$ & $0.13(0.15)$ \\
\hline Grain yield & $0.16^{\star}(0.03)$ & $-0.01\left(-0.17^{\star}\right)$ & $0.24^{\star \star}(0.05)$ & $0.05\left(0.22^{\star}\right)$ \\
\hline Panicle compactness & $-0.13\left(-0.55^{\star \star}\right)$ & $-0.01\left(-0.18^{\star}\right)$ & $-0.30^{\star \star}\left(-0.60^{\star \star}\right)$ & $-0.28^{\star \star}\left(-0.45^{\star \star}\right)$ \\
\hline Panicle shape & $\left(-0.48^{\star \star}\right)$ & $(-0.10)$ & $\left(-0.49^{\star \star}\right)$ & $\left(-0.38^{\star \star}\right)$ \\
\hline Glume coverage & $-0.17^{\star}\left(-0.16^{\star}\right)$ & $0.15(0.08)$ & $-0.18^{\star}\left(-0.44^{\star \star}\right)$ & $-0.01(-0.13)$ \\
\hline Awns & $-0.12\left(-0.41^{\star *}\right)$ & $0.01(-0.07)$ & $-0.18^{\star}\left(-0.44^{\star \star}\right)$ & $0.10\left(-0.17^{\star}\right)$ \\
\hline
\end{tabular}

${ }^{*},{ }^{* *}$ Correlation coefficients significant at P 0.05 and $P 0.01$, respectively; ORS, overall resistance score; The values inside the parentheses are for postrainy season, whereas the values outside the parentheses are for rainy season.

\section{TABLE 4 | Association between the agronomic traits in the postrainy} season adapted sorghums (ICRISAT, Patancheru, 2013-14).

\begin{tabular}{|c|c|c|c|c|}
\hline Traits & $\begin{array}{l}\text { Agronomic } \\
\text { score }\end{array}$ & $\begin{array}{c}\text { Days to } 50 \% \\
\text { flowering }\end{array}$ & $\begin{array}{l}\text { Plant } \\
\text { height }\end{array}$ & $\begin{array}{c}100 \text { seed } \\
\text { weight }\end{array}$ \\
\hline $\begin{array}{l}\text { Days to } 50 \% \\
\text { flowering }\end{array}$ & $0.24^{\star \star}\left(0.45^{\star \star}\right)$ & 1.00 & & \\
\hline Plant height & $0.52^{\star \star}\left(0.24^{\star \star}\right)$ & $0.22^{*}\left(0.41^{* \star}\right)$ & 1.00 & \\
\hline $\begin{array}{l}100 \text { seed } \\
\text { weight }\end{array}$ & $-0.17(0.01)$ & $-0.51^{\star \star}\left(-0.23^{\star \star}\right)$ & $0.04\left(0.43^{\star \star}\right)$ & 1.00 \\
\hline Grain yield & $-0.47^{\star \star}\left(-0.21^{\star}\right)$ & $-0.26^{\star \star}(-0.08)$ & $0.00\left(0.36^{\star \star}\right)$ & $0.36^{\star \star}\left(0.21^{\star}\right)$ \\
\hline
\end{tabular}

${ }^{*},{ }^{* \star}$ Correlation coefficients significant at $P 0.05$ and $P 0.01$, respectively; The values inside the parentheses are for postrainy season, whereas the values outside the parentheses are for rainy season.

X IS 2146 in the postrainy season. Four hybrids across seasons, seven in the rainy season and eight hybrids in the postrainy season, exhibited significant and positive sca effects for grain yield. ICSV 700 X CSV 15, Phule Anuradha X M 35-1, Phule Anuradha X IS 18551, M 35-1 X IS 18551, CSV 15 X ICSV
TABLE 5 | Association between the panicle traits in the postrainy season sorghums (ICRISAT, Patancheru, 2013-14).

\begin{tabular}{|c|c|c|c|c|c|}
\hline Traits & $\begin{array}{l}\text { Inflorescence } \\
\text { exsertion }\end{array}$ & $\begin{array}{c}\text { Panicle } \\
\text { compactness }\end{array}$ & $\begin{array}{l}\text { Panicle } \\
\text { shape }\end{array}$ & $\begin{array}{c}\text { Glume } \\
\text { coverage }\end{array}$ & Awns \\
\hline $\begin{array}{l}\text { Panicle } \\
\text { compactness }\end{array}$ & $0.66^{\star \star}\left(0.66^{\star \star}\right)$ & 1.00 & & & \\
\hline Panicle shape & $\left(0.46^{\star \star}\right)$ & $\left(0.86^{\star \star}\right)$ & 1.00 & & \\
\hline $\begin{array}{l}\text { Glume } \\
\text { coverage }\end{array}$ & $-0.03(-0.14)$ & $-0.12(0.05)$ & $(0.07)$ & 1.00 & \\
\hline Awns & $0.45^{\star \star}\left(0.53^{\star \star}\right)$ & $0.30^{\star \star}\left(0.52^{\star \star}\right)$ & $\left(0.44^{\star \star}\right)$ & $0.44^{\star \star}\left(0.29^{\star \star}\right)$ & 1.00 \\
\hline Grain luster & $(0.10)$ & $(0.01)$ & $(-0.03)$ & $\left(-0.55^{\star \star}\right)$ & $(-0.13)$ \\
\hline
\end{tabular}

${ }^{*},{ }^{* *}$ Correlation coefficient significant at $P 0.05$ and $P 0.01$, respectively; The values inside the parentheses are for postrainy season, whereas the values outside the parentheses are for rainy season.

25019, ICSV 25019 X Swarna, PS 35805 X Swarna, IS 2123 X IS 2146 exhibited significant negative sca effects while ICSV 700 X Swarna, M 35-1 X PS 35805, CSV 15 X IS 2123, CSV 15 X Swarna, ICSV 25019 X IS 2123, ICSV 25019 X IS 2146 exhibited 


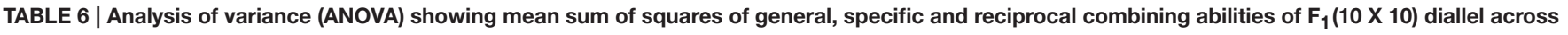
seasons (ICRISAT, Patancheru, 2013-14).

\begin{tabular}{|c|c|c|c|c|c|c|c|c|}
\hline \multirow[t]{2}{*}{ Source } & \multicolumn{2}{|c|}{ GCA } & \multicolumn{2}{|c|}{ SCA } & \multicolumn{2}{|c|}{ Reciprocal } & \multicolumn{2}{|c|}{ Error } \\
\hline & 2013 R & 2013 PR & 2013 R & 2013 PR & 2013 R & 2013 PR & 2013 R & 2013 PR \\
\hline Days to $50 \%$ flowering & $75.23^{\star \star}$ & $168.15^{\star \star}$ & $10.31^{\star *}$ & $8.40^{* *}$ & $2.74^{* *}$ & $4.92^{\star \star}$ & 1.27 & 1.96 \\
\hline Plant height (cm) & $14639.30^{\star *}$ & $5747.19^{* *}$ & $1856.50^{* \star}$ & $494.31^{\star *}$ & 40.27 & $69.04^{\star *}$ & 38.62 & 33.99 \\
\hline 100 seed weight (g) & $0.81^{\star *}$ & $2.07^{* \star}$ & $0.10^{* *}$ & $0.18^{\star *}$ & $0.02^{*}$ & $0.05^{\star *}$ & 0.02 & 0.02 \\
\hline Grain yield (t/ha) & $11.80^{\star *}$ & $44.52^{\star \star}$ & $3.94^{\star *}$ & $12.95^{\star *}$ & 0.70 & 1.08 & 0.50 & 1.08 \\
\hline Agronomic score & $6.83^{\star \star}$ & $3.06^{\star \star}$ & $0.44^{\star *}$ & 0.15 & 0.17 & 0.11 & 0.12 & 0.16 \\
\hline Inflorescence exsertion & $2.14^{\star \star}$ & $10.80^{\star \star}$ & $0.34^{\star *}$ & $0.58^{\star \star}$ & $0.11^{* *}$ & 0.11 & 0.06 & 0.09 \\
\hline Panicle compactness & $1.68^{\star *}$ & $1.74^{\star \star}$ & $0.08^{\star *}$ & $0.17^{\star \star}$ & 0.01 & $0.03^{\star *}$ & 0.01 & 0.01 \\
\hline Panicle shape & - & $4.88^{\star \star}$ & - & $1.40^{\star \star}$ & - & $0.32^{\star \star}$ & - & 0.13 \\
\hline Glume coverage & $17.63^{\star \star}$ & $21.08^{* \star}$ & $0.70^{\star *}$ & $0.49^{\star \star}$ & 0.21 & 0.03 & 0.19 & 0.11 \\
\hline Awns & $1.91^{\star \star}$ & $1.85^{\star \star}$ & $0.13^{\star *}$ & $0.13^{\star *}$ & 0.00 & 0.00 & 0.00 & 0.00 \\
\hline Grain luster & $0.02^{\star *}$ & $0.04^{\star \star}$ & 0.02 & $0.02^{\star *}$ & 0.00 & 0.01 & 0.00 & 0.00 \\
\hline
\end{tabular}

${ }^{\star},{ }^{\star \star} F$ probability significant at $P 0.05$ and $P$ 0.01, respectively; GCA, general combining ability; SCA, specific combining ability; $R$, rainy season; PR, postrainy season.

TABLE 7 | Estimates of general combining ability of agronomic and panicle traits of parents (10 X 10 diallel) across seasons (ICRISAT, Patancheru, 2013-14).

\begin{tabular}{|c|c|c|c|c|c|c|c|c|c|c|}
\hline Traits & ICSV 700 & $\begin{array}{l}\text { Phule } \\
\text { Anuradha }\end{array}$ & M 35-1 & CSV 15 & $\begin{array}{l}\text { ICSV } \\
25019\end{array}$ & PS 35805 & IS 2123 & IS 2146 & IS 18551 & Swarna \\
\hline Days to $50 \%$ flowering & $\begin{array}{l}3.36^{\star \star} \\
\left(4.40^{\star \star}\right)\end{array}$ & $\begin{array}{l}-2.87^{\star \star} \\
\left(-1.61^{\star \star}\right)\end{array}$ & $\begin{array}{l}0.50^{\star} \\
\left(2.30^{\star \star}\right)\end{array}$ & $\begin{array}{c}-0.35 \\
\left(-3.65^{\star \star}\right)\end{array}$ & $\begin{array}{l}-1.85^{\star \star} \\
\left(-2.58^{\star \star}\right)\end{array}$ & $\begin{array}{c}-0.44 \\
\left(-2.58^{\star \star}\right)\end{array}$ & $\begin{array}{l}1.33^{\star \star} \\
\left(1.70^{\star *}\right)\end{array}$ & $\begin{array}{c}-0.77^{\star \star} \\
\left(1.44^{\star \star}\right)\end{array}$ & $\begin{array}{l}2.46^{\star \star} \\
\left(3.17^{\star \star}\right)\end{array}$ & $\begin{array}{l}-1.37^{\star *} \\
\left(-2.60^{\star \star}\right)\end{array}$ \\
\hline Plant height (cm) & $\begin{array}{l}32.23^{\star \star} \\
\left(19.42^{\star \star}\right)\end{array}$ & $\begin{array}{l}5.59^{\star \star} \\
\left(7.92^{\star \star}\right)\end{array}$ & $\begin{array}{l}19.43^{\star \star} \\
\left(10.53^{\star \star}\right)\end{array}$ & $\begin{array}{l}5.19^{\star \star} \\
(1.87)\end{array}$ & $\begin{array}{l}-44.49^{\star \star} \\
\left(-28.69^{\star \star}\right)\end{array}$ & $\begin{array}{l}-42.96^{\star \star} \\
\left(-27.69^{\star \star}\right)\end{array}$ & $\begin{array}{l}3.87^{\star \star} \\
(-2.13)\end{array}$ & $\begin{array}{l}5.96^{\star *} \\
(1.53)\end{array}$ & $\begin{array}{l}31.29^{\star \star} \\
\left(20.59^{\star \star}\right)\end{array}$ & $\begin{array}{l}-16.10^{\star \star} \\
\left(-3.36^{\star *}\right)\end{array}$ \\
\hline 100 seed weight $(\mathrm{g})$ & $\begin{array}{l}-0.02 \\
\left(0.07^{\star}\right)\end{array}$ & $\begin{array}{l}0.20^{\star *} \\
\left(0.56^{\star \star}\right)\end{array}$ & $\begin{array}{c}0.01 \\
\left(0.33^{\star \star}\right)\end{array}$ & $\begin{array}{r}0.09 * \star \\
(0.01)\end{array}$ & $\begin{array}{c}0.04 \\
\left(-0.22^{\star \star}\right)\end{array}$ & $\begin{array}{l}-0.07^{\star \star} \\
\left(-0.43^{\star \star}\right)\end{array}$ & $\begin{array}{c}-0.06^{\star} \\
\left(-0.16^{\star \star}\right)\end{array}$ & $\begin{array}{l}-0.26^{\star \star} \\
(-0.05)\end{array}$ & $\begin{array}{l}-0.31^{\star *} \\
\left(-0.40^{\star *}\right)\end{array}$ & $\begin{array}{l}0.38^{\star *} \\
\left(0.29^{\star \star}\right)\end{array}$ \\
\hline Grain yield (t/ha) & $\begin{array}{c}0.23 \\
\left(0.44^{\star}\right)\end{array}$ & $\begin{array}{c}-0.43^{\star \star} \\
\left(0.52^{\star}\right)\end{array}$ & $\begin{array}{l}-0.34^{\star} \\
\left(1.27^{\star \star}\right)\end{array}$ & $\begin{array}{l}0.90^{\star \star} \\
\left(0.86^{\star \star}\right)\end{array}$ & $\begin{array}{r}0.40^{* \star} \\
(0.07)\end{array}$ & $\begin{array}{r}0.48^{\star \star} \\
(0.03)\end{array}$ & $\begin{array}{c}-0.14 \\
\left(0.89^{\star *}\right)\end{array}$ & $\begin{array}{l}-1.79^{\star \star} \\
\left(-3.86^{\star \star}\right)\end{array}$ & $\begin{array}{c}-0.06 \\
\left(0.77^{\star \star}\right)\end{array}$ & $\begin{array}{c}0.74^{\star *} \\
\left(-0.99^{\star \star}\right)\end{array}$ \\
\hline Agronomic score & $\begin{array}{l}0.13 \\
(0.04)\end{array}$ & $\begin{array}{l}0.18^{\star} \\
(0.11)\end{array}$ & $\begin{array}{c}0.26^{\star *} \\
(0.11)\end{array}$ & $\begin{array}{l}-0.46^{\star \star} \\
\left(-0.31^{\star \star}\right)\end{array}$ & $\begin{array}{l}-0.73^{\star \star} \\
\left(-0.39^{\star \star}\right)\end{array}$ & $\begin{array}{l}-0.75^{\star \star} \\
\left(-0.31^{\star \star}\right)\end{array}$ & $\begin{array}{l}0.96^{\star \star} \\
\left(0.59^{\star *}\right)\end{array}$ & $\begin{array}{l}0.69^{\star *} \\
\left(0.66^{\star \star}\right)\end{array}$ & $\begin{array}{l}0.18^{\star} \\
(-0.01)\end{array}$ & $\begin{array}{l}-0.47^{\star \star} \\
\left(-0.48^{\star \star}\right)\end{array}$ \\
\hline Inflorescence exsertion & $\begin{array}{c}-0.05 \\
\left(-0.18^{\star \star}\right)\end{array}$ & $\begin{array}{l}0.12^{\star} \\
\left(0.17^{\star \star}\right)\end{array}$ & $\begin{array}{l}-0.13^{\star} \\
\left(-0.16^{\star}\right)\end{array}$ & $\begin{array}{l}-0.23^{\star \star} \\
\left(-0.53^{\star \star}\right)\end{array}$ & $\begin{array}{c}0.00 \\
\left(-0.16^{\star}\right)\end{array}$ & $\begin{array}{l}0.13^{\star} \\
\left(-0.21^{\star \star}\right)\end{array}$ & $\begin{array}{l}0.57^{\star \star} \\
\left(1.51^{\star \star}\right)\end{array}$ & $\begin{array}{l}0.35^{\star \star} \\
\left(0.96^{\star \star}\right)\end{array}$ & $\begin{array}{c}-0.12^{\star} \\
\left(-0.34^{\star \star}\right)\end{array}$ & $\begin{array}{l}-0.63^{\star *} \\
\left(-1.06^{\star \star}\right)\end{array}$ \\
\hline Panicle compactness & $\begin{array}{r}-0.17^{\star *} \\
\left(0.13^{\star \star}\right)\end{array}$ & $\begin{array}{c}-0.13^{\star *} \\
(0.00)\end{array}$ & $\begin{array}{c}-0.15^{\star *} \\
\left(0.13^{\star \star}\right)\end{array}$ & $\begin{array}{l}-0.20^{\star \star} \\
\left(-0.50^{\star \star}\right)\end{array}$ & $\begin{array}{c}-0.03 \\
\left(-0.10^{\star \star}\right)\end{array}$ & $0.02\left(0.05^{\star}\right)$ & $\begin{array}{l}0.62^{* \star} \\
\left(0.37^{\star *}\right)\end{array}$ & $\begin{array}{l}0.43^{\star \star} \\
\left(0.37^{\star *}\right)\end{array}$ & $\begin{array}{c}-0.13^{\star *} \\
(0.02)\end{array}$ & $\begin{array}{l}-0.25^{\star \star} \\
\left(-0.47^{\star \star}\right)\end{array}$ \\
\hline Panicle shape & $\left(0.41^{\star \star}\right)$ & $(0.01)$ & $\left(0.35^{\star \star}\right)$ & $\left(-0.70^{\star \star}\right)$ & $\left(-0.24^{\star \star}\right)$ & $\left(0.20^{\star \star}\right)$ & $\left(0.31^{\star \star}\right)$ & $\left(0.58^{\star \star}\right)$ & $(0.01)$ & $\left(-0.94^{\star *}\right)$ \\
\hline Glume coverage & $\begin{array}{r}0.35^{\star \star} \\
(0.03)\end{array}$ & $\begin{array}{l}-0.28^{\star \star} \\
\left(-0.31^{\star \star}\right)\end{array}$ & $\begin{array}{c}-0.05 \\
\left(-0.27^{\star \star}\right)\end{array}$ & $\begin{array}{l}-0.65^{\star \star} \\
\left(-0.31^{\star \star}\right)\end{array}$ & $\begin{array}{l}-0.65^{\star \star} \\
\left(-0.51^{\star \star}\right)\end{array}$ & $\begin{array}{l}-0.55^{\star \star} \\
\left(-0.44^{\star \star}\right)\end{array}$ & $\begin{array}{c}-0.01 \\
\left(-0.37^{\star \star}\right)\end{array}$ & $\begin{array}{l}-0.31^{\star *} \\
\left(-0.41^{\star *}\right)\end{array}$ & $\begin{array}{l}2.52^{\star \star} \\
\left(2.89^{\star \star}\right)\end{array}$ & $\begin{array}{l}-0.38^{\star *} \\
\left(-0.31^{\star \star}\right)\end{array}$ \\
\hline Awns & $\begin{array}{l}0.24^{\star \star} \\
\left(0.25^{\star \star}\right)\end{array}$ & $\begin{array}{l}0.24^{\star \star} \\
\left(0.21^{\star \star}\right)\end{array}$ & $\begin{array}{l}0.24^{\star \star} \\
\left(0.23^{\star \star}\right)\end{array}$ & $\begin{array}{l}-0.35^{\star \star} \\
\left(-0.35^{\star \star}\right)\end{array}$ & $\begin{array}{l}-0.36^{\star \star} \\
\left(-0.35^{\star \star}\right)\end{array}$ & $\begin{array}{l}-0.36^{\star \star} \\
\left(-0.35^{\star \star}\right)\end{array}$ & $\begin{array}{l}0.24^{\star \star} \\
\left(0.25^{\star \star}\right)\end{array}$ & $\begin{array}{l}0.24^{\star \star} \\
\left(0.23^{\star \star}\right)\end{array}$ & $\begin{array}{l}0.25^{\star \star} \\
\left(0.25^{\star \star}\right)\end{array}$ & $\begin{array}{c}-0.36^{\star \star} \\
\left(-0.35^{\star \star}\right)\end{array}$ \\
\hline Grain luster & $(0.01)$ & $(0.01)$ & $(0.01)$ & $(0.01)$ & $(0.02)$ & $(0.01)$ & $(0.02)$ & $(0.02)$ & $\left(-0.13^{\star \star}\right)$ & $(0.02)$ \\
\hline
\end{tabular}

*, **t-test significant at 0.05 and 0.01 probability levels; The values outside the parentheses are for rainy season and inside the parentheses are for postrainy season.

significant positive sca effects for agronomic score in the rainy season.

\section{sca Effects of Morphological Traits}

The sca effects of the inflorescence exsertion ranged from -0.92 to 0.95 and -0.91 to 1.11 , for panicle compactness from -0.52 to 0.37 and -0.67 to 0.50 , for glume coverage -1.22 to 0.78 and -1.09 to 0.71 , for awns from -0.25 to 0.36 and 0.25 to 0.35 , respectively, in the rainy and postrainy seasons. For panicle shape it ranged from -1.46 to 1.60 and grain luster from -0.16 to -0.01 in the postrainy season (Table 9). The genotypes with significant $g c a$ and/or sca for morphological traits can be utilized in developing sorghum cultivars for use by the farmers.

\section{Reciprocal Combining Ability Effects of Agronomic and Morphological Traits}

M 35-1 X ICSV 700, ICSV 25019 X M 35-1, IS 18551 X ICSV 700, IS 18551 X M 35-1, IS 18551 X PS 35805, IS 18551 X IS 2123 in the rainy season, PS $35805 \mathrm{X}$ Phule Anuradha in the postrainy 
TABLE 8 | Estimates of specific combining ability effects of agronomic traits of $F_{1}$ crosses (10 X 10 diallel) of sorghum across seasons (ICRISAT, Patancheru, 2013-14).

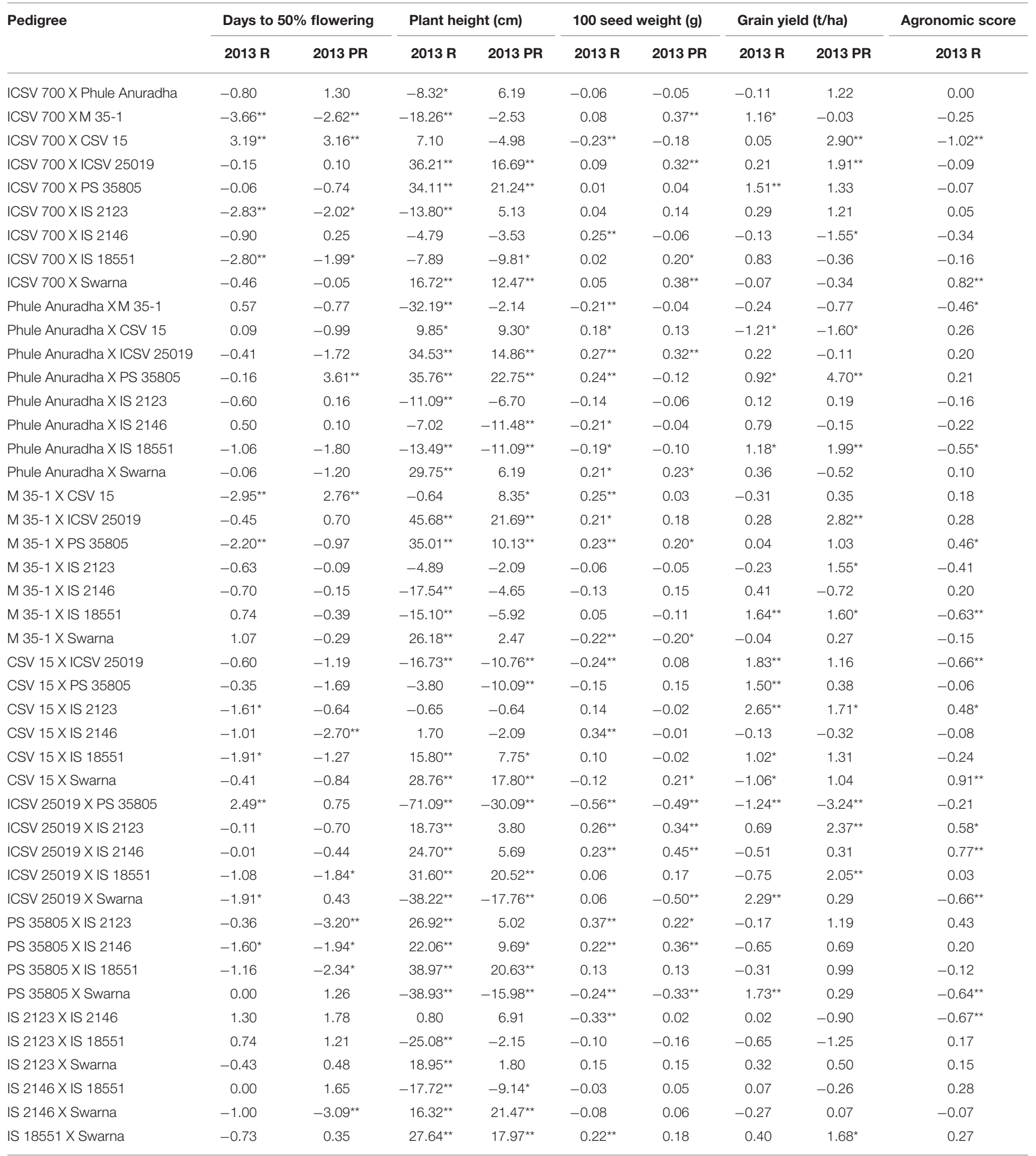

${ }^{*},{ }^{*}$ t-test significant at $P 0.05$ and $P 0.01$ respectively; $R$, rainy season; $P R$, postrainy season.

season, and PS $35805 \mathrm{X}$ Phule Anuradha across seasons, exhibited significant negative reciprocal effects for days to $50 \%$ flowering (Table 10). CSV 15 X ICSV 700 and Swarna X IS 18551 in the rainy season, six hybrids in the postrainy season, and Swarna X M 35-1 and Swarna X IS 2123 across seasons exhibited significant positive reciprocal effects for days to $50 \%$ flowering. The crosses 
TABLE 9 | Estimates of specific combining ability effects of panicle traits of $F_{1}$ crosses (10 X 10 diallel) of sorghum, across seasons (ICRISAT, Patancheru, 2013-14).

\begin{tabular}{|c|c|c|c|c|c|c|c|c|c|c|}
\hline Pedigree & \multicolumn{2}{|c|}{ Inflorescence exsertion } & \multicolumn{2}{|c|}{ Panicle compactness } & $\frac{\text { Panicle shape }}{2013 \text { PR }}$ & \multicolumn{2}{|c|}{ Glume coverage } & \multicolumn{2}{|c|}{ Awns } & $\frac{\text { Grain luster }}{2013 \text { PR }}$ \\
\hline ICSV 700 XM 35-1 & 0.10 & $0.43^{*}$ & -0.02 & 0.10 & $0.49^{\star}$ & $-0.65^{\star}$ & $-0.46^{\star}$ & $0.16^{\star \star}$ & $0.17^{\star \star}$ & 0.01 \\
\hline ICSV 700 X CSV 15 & 0.03 & -0.37 & 0.03 & -0.10 & $-0.63^{\star \star}$ & -0.39 & $-0.43^{*}$ & $-0.25^{\star \star}$ & $-0.25^{\star \star}$ & 0.01 \\
\hline ICSV 700 X ICSV 25019 & $-0.37^{\star}$ & $-0.41^{*}$ & -0.13 & $-0.17^{*}$ & -0.43 & -0.39 & -0.23 & $-0.24^{\star \star}$ & $-0.25^{\star \star}$ & -0.01 \\
\hline ICSV 700 X IS 2146 & -0.05 & 0.14 & 0.07 & -0.13 & -0.41 & -0.05 & -0.33 & $0.16^{\star \star}$ & $0.17^{\star \star}$ & -0.01 \\
\hline ICSV 700 X IS 18551 & -0.08 & $0.61^{* *}$ & -0.03 & $0.22^{\star \star}$ & $0.82^{\star \star}$ & $0.78^{\star \star}$ & $-0.63^{* *}$ & $0.15^{\star \star}$ & $0.15^{\star \star}$ & -0.02 \\
\hline ICSV 700 X Swarna & $0.43^{\star \star}$ & -0.17 & 0.08 & $-0.30^{\star \star}$ & $-1.23^{\star \star}$ & -0.32 & -0.09 & $-0.24^{\star *}$ & $-0.25^{\star *}$ & -0.01 \\
\hline Phule Anuradha XM 35-1 & 0.27 & 0.08 & -0.05 & $-0.27^{\star \star}$ & $-0.61^{\star \star}$ & $-0.687^{*}$ & -0.13 & $0.16^{\star \star}$ & 0.04 & $-0.16^{\star \star}$ \\
\hline Phule Anuradha X CSV 15 & -0.30 & $-0.56^{\star \star}$ & 0.00 & -0.13 & $-0.56^{\star}$ & -0.09 & -0.09 & $-0.25^{\star \star}$ & $-0.21^{\star \star}$ & 0.01 \\
\hline Phule Anuradha X IS 2146 & 0.28 & $0.46^{*}$ & $0.20^{*}$ & 0.00 & -0.35 & 0.25 & 0.01 & $0.16^{\star \star}$ & 0.04 & -0.01 \\
\hline Phule Anuradha X IS 18551 & 0.25 & 0.26 & -0.07 & $0.35^{\star \star}$ & $1.22^{\star \star}$ & $-0.59^{*}$ & $0.71^{* \star}$ & $0.15^{\star \star}$ & $0.19^{\star \star}$ & $0.14^{\star \star}$ \\
\hline Phule Anuradha X Swarna & -0.07 & -0.36 & 0.05 & $-0.17^{\star}$ & $-0.66^{\star \star}$ & -0.02 & -0.09 & $-0.24^{\star *}$ & $-0.21^{\star *}$ & -0.01 \\
\hline M 35-1 X CSV 15 & $-0.38^{*}$ & $-0.56^{\star \star}$ & 0.02 & -0.10 & -0.40 & -0.32 & $0.54^{*}$ & $-0.25^{\star \star}$ & $-0.23^{\star *}$ & 0.01 \\
\hline M 35-1 X ICSV 25019 & $-0.62^{\star *}$ & $-0.76^{* *}$ & -0.15 & $-0.33^{\star \star}$ & $-0.86^{\star \star}$ & 0.01 & 0.07 & $-0.24^{\star \star}$ & $-0.23^{\star *}$ & -0.01 \\
\hline M 35-1 X PS 35805 & $-0.92^{\star \star}$ & $-0.54^{* *}$ & -0.03 & $0.18^{*}$ & $0.70^{\star \star}$ & $0.58^{\star}$ & 0.01 & $-0.24^{\star *}$ & $-0.23^{\star \star}$ & 0.01 \\
\hline M 35-1 X IS 2123 & 0.15 & 0.24 & 0.03 & -0.13 & -0.41 & -0.29 & -0.06 & $0.16^{\star \star}$ & $0.17^{\star *}$ & -0.01 \\
\hline M 35-1 X IS 2146 & $0.37^{\star}$ & $0.79^{\star \star}$ & $0.22^{\star \star}$ & -0.13 & $-0.68^{\star \star}$ & $-0.65^{*}$ & -0.03 & $0.16^{\star \star}$ & $0.19^{\star \star}$ & -0.01 \\
\hline M 35-1 X IS 18551 & 0.17 & $0.43^{\star}$ & -0.05 & $0.22^{* \star}$ & $0.89^{\star \star}$ & 0.51 & 0.34 & $0.15^{\star \star}$ & $0.17^{\star \star}$ & $0.14^{\star \star}$ \\
\hline M 35-1 X Swarna & $0.52^{\star \star}$ & -0.02 & 0.07 & $0.37^{\star \star}$ & 0.34 & 0.41 & -0.13 & $-0.24^{\star *}$ & $-0.23^{\star \star}$ & -0.01 \\
\hline ICSV 25019 X IS 2123 & 0.02 & 0.08 & 0.08 & 0.10 & 0.17 & -0.02 & 0.17 & $-0.24^{\star \star}$ & $-0.25^{\star \star}$ & -0.02 \\
\hline ICSV 25019 X IS 2146 & 0.07 & $0.63^{\star \star}$ & 0.10 & 0.10 & $0.57^{\star}$ & -0.05 & 0.21 & $-0.24^{\star \star}$ & $-0.23^{\star \star}$ & -0.02 \\
\hline ICSV 25019 X IS 18551 & $-0.63^{\star *}$ & $-0.91^{* *}$ & $-0.17^{*}$ & $-0.22^{\star \star}$ & $-0.53^{\star}$ & -0.55 & $-1.09^{* *}$ & $-0.25^{\star \star}$ & $-0.25^{\star \star}$ & $0.13^{\star \star}$ \\
\hline ICSV 25019 X Swarna & -0.28 & -0.02 & -0.05 & -0.07 & $-0.58^{\star}$ & 0.01 & 0.11 & $0.36^{\star *}$ & $0.35^{\star \star}$ & -0.02 \\
\hline PS 35805 X IS 2123 & -0.12 & 0.13 & 0.03 & -0.05 & -0.26 & 0.21 & 0.11 & $-0.24^{\star \star}$ & $-0.25^{\star \star}$ & -0.01 \\
\hline PS 35805 X IS 2146 & 0.10 & 0.34 & $0.22^{\star \star}$ & -0.05 & -0.03 & -0.15 & 0.14 & $-0.24^{\star \star}$ & $-0.23^{\star \star}$ & -0.01 \\
\hline PS 35805 X IS 18551 & $-0.43^{\star \star}$ & -0.36 & $-0.22^{\star *}$ & $-0.53^{\star *}$ & $-1.46^{\star \star}$ & -0.32 & $-0.49^{*}$ & $-0.25^{\star \star}$ & $-0.25^{\star *}$ & -0.02 \\
\hline PS 35805 X Swarna & $-0.47^{\star}$ & -0.14 & -0.10 & $-0.22^{\star \star}$ & $-1.01^{\star \star}$ & -0.09 & 0.04 & $0.36^{\star \star}$ & $0.35^{\star \star}$ & -0.01 \\
\hline IS 2123 X IS 2146 & 0.17 & $-0.87^{\star \star}$ & $-0.38^{* \star}$ & $-0.37^{\star *}$ & $-0.65^{\star \star}$ & -0.02 & 0.07 & $0.16^{\star \star}$ & $0.17^{\star \star}$ & -0.02 \\
\hline IS 2123 X IS 18551 & $0.47^{\star \star}$ & $0.43^{\star}$ & $0.18^{*}$ & -0.02 & -0.08 & -0.19 & 0.11 & $0.15^{\star \star}$ & $0.15^{\star \star}$ & $0.13^{\star \star}$ \\
\hline IS 2123 X Swarna & -0.02 & $0.64^{\star \star}$ & 0.13 & $0.47^{\star \star}$ & $1.37^{\star \star}$ & $-0.62^{*}$ & -0.03 & $-0.24^{\star \star}$ & $-0.25^{\star \star}$ & -0.02 \\
\hline IS 2146 X IS 18551 & $0.52^{\star \star}$ & -0.36 & $0.37^{\star \star}$ & -0.02 & -0.35 & $-1.22^{* *}$ & $-0.53^{*}$ & $0.15^{\star \star}$ & $0.17^{\star \star}$ & $0.13^{\star \star}$ \\
\hline IS 2146 X Swarna & -0.30 & $-0.81^{\star \star}$ & $-0.52^{\star \star}$ & $0.47^{\star \star}$ & $1.60^{\star \star}$ & 0.35 & 0.01 & $-0.24^{\star \star}$ & $-0.23^{\star \star}$ & -0.02 \\
\hline IS 18551 X Swarna & -0.17 & -0.01 & 0.05 & $-0.18^{*}$ & $-0.83^{\star \star}$ & 0.18 & 0.37 & $-0.25^{\star *}$ & $-0.25^{\star \star}$ & $0.13^{\star \star}$ \\
\hline
\end{tabular}

*, ** Significant at $P 0.05$ and $P 0.01$ probability levels; $R$, rainy season; PR, postrainy season.

CSV 15 X Phule Anuradha, PS 35805 X Phule Anuradha, PS 35805 X ICSV 700, and Swarna X CSV 15 exhibited significant negative and the crosses Phule Anuradha X ICSV 700, ICSV
25019 X M 35-1, IS 18551 X ICSV 700, and Swarna X IS 2123 showed significant positive reciprocal effects for plant height in the postrainy season. 
TABLE 10 | Estimates of reciprocal combining ability effects of reciprocal crosses (10 X 10 diallel) of sorghum across seasons (ICRISAT, Patancheru, 2013-14).

\begin{tabular}{|c|c|c|c|c|c|c|c|c|}
\hline \multirow[t]{2}{*}{ Pedigree } & \multicolumn{2}{|c|}{ Days to $50 \%$ flowering } & \multirow{2}{*}{$\frac{\text { Plant height }(\mathrm{cm})}{2013 \mathrm{PR}}$} & \multicolumn{2}{|c|}{100 seed weight (g) } & \multirow{2}{*}{$\frac{\text { Inflorescence exsertion }}{2013 \mathrm{R}}$} & \multirow{2}{*}{$\begin{array}{c}\text { Panicle compactness } \\
2013 \text { PR }\end{array}$} & \multirow{2}{*}{$\begin{array}{c}\text { Panicle shape } \\
2013 \text { PR }\end{array}$} \\
\hline & $2013 \mathrm{R}$ & 2013 PR & & 2013 R & 2013 PR & & & \\
\hline Phule Anuradha X ICSV 700 & -0.50 & $5.33^{\star *}$ & $11.11^{\star \star}$ & 0.03 & $-0.20^{*}$ & - & - & - \\
\hline M 35-1 X ICSV 700 & $-1.70^{*}$ & 0.33 & -0.56 & -0.02 & -0.15 & 0.17 & - & - \\
\hline M 35-1 X Phule Anuradha & -0.33 & 0.83 & -5.00 & 0.02 & 0.13 & -0.17 & $0.17^{\star}$ & $0.50^{*}$ \\
\hline CSV $15 \times$ ICSV 700 & $3.00^{\star *}$ & 1.50 & 1.67 & -0.05 & 0.02 & - & $-0.17^{\star}$ & $-0.50^{*}$ \\
\hline ICSV 25019 X ICSV 700 & -0.83 & 0.50 & 0.56 & 0.12 & 0.08 & $0.50^{\star *}$ & $-0.17^{\star}$ & $-0.50^{*}$ \\
\hline ICSV 25019 X Phule Anuradha & $a-0.33$ & 0.33 & -1.67 & $-0.20^{\star *}$ & -0.08 & $0.30^{*}$ & $-0.17^{\star}$ & $-0.50^{*}$ \\
\hline ICSV 25019 XM 35-1 & $-1.70^{*}$ & $-3.00^{\star *}$ & $8.89^{*}$ & -0.07 & 0.17 & -0.17 & $-0.33^{\star *}$ & $-1.00^{* *}$ \\
\hline ICSV 25019 X CSV 15 & -0.67 & -1.50 & -4.44 & - & $0.25^{\star}$ & 0.17 & - & -0.17 \\
\hline PS 35805 X ICSV 700 & $-2.00^{\star *}$ & 0.67 & 0.56 & -0.03 & - & 0.17 & - & - \\
\hline PS 35805 X ICSV 25019 & -0.33 & -0.50 & - & -0.02 & 0.18 & - & - & - \\
\hline IS $2123 \times$ ICSV 700 & - & -0.67 & 5.56 & -0.03 & -0.03 & $-0.30^{*}$ & - & - \\
\hline IS 2123 X Phule Anuradha & -0.67 & -1.17 & -2.22 & 0.02 & 0.10 & - & - & - \\
\hline IS 2123 XM 35-1 & -1.33 & 0.83 & 0.56 & 0.10 & - & $-0.50^{\star *}$ & - & - \\
\hline IS 2123 X CSV 15 & 0.50 & -1.33 & -5.56 & -0.08 & 0.02 & $-0.30^{*}$ & - & 0.17 \\
\hline IS 2123 X ICSV 25019 & -1.17 & -0.67 & 2.78 & 0.05 & 0.15 & $0.50^{\star *}$ & - & - \\
\hline IS 2123 X PS 35805 & - & $1.83^{\star}$ & -5.00 & -0.08 & -0.12 & -0.17 & - & - \\
\hline IS 2146 X ICSV 700 & 1.17 & - & -0.56 & -0.02 & 0.18 & -0.17 & - & - \\
\hline IS 2146 X Phule Anuradha & 1.00 & 0.83 & -2.22 & -0.12 & 0.13 & - & - & - \\
\hline IS 2146 XM 35-1 & -1.17 & 0.50 & -0.56 & - & 0.12 & -0.17 & - & - \\
\hline IS 2146 X CSV 15 & - & $3.00^{\star *}$ & 4.45 & 0.02 & -0.03 & $0.50^{\star \star}$ & - & -0.17 \\
\hline IS 18551 X ICSV 25019 & -0.33 & 1.00 & 5.56 & - & -0.03 & -0.17 & $0.33^{\star \star}$ & $1.00^{* *}$ \\
\hline IS 18551 X PS 35805 & $-1.70^{*}$ & -0.17 & -2.22 & 0.10 & -0.08 & -0.17 & $-0.17^{\star}$ & $-0.50^{*}$ \\
\hline IS 18551 XIS 2123 & $-2.00^{* *}$ & $2.00^{*}$ & -0.56 & -0.12 & -0.17 & -0.17 & - & - \\
\hline IS 18551 X IS 2146 & -0.50 & 0.50 & 7.22 & 0.12 & 0.05 & $-0.30^{*}$ & - & - \\
\hline Swarna X ICSV 700 & -0.33 & 0.67 & -6.11 & 0.08 & -0.08 & $0.30^{*}$ & - & - \\
\hline Swarna X Phule Anuradha & 0.83 & $1.83^{*}$ & -2.78 & 0.07 & -0.13 & $0.30^{*}$ & - & -0.17 \\
\hline Swarna XM 35-1 & $2.30^{* \star}$ & $2.33^{*}$ & 7.22 & $-0.40^{\star \star}$ & $-0.67^{\star \star}$ & $0.30^{*}$ & $0.33^{\star \star}$ & $1.50^{\star \star}$ \\
\hline Swarna X CSV 15 & 0.67 & 0.83 & $-9.45^{\star}$ & $0.20^{*}$ & $-0.22^{*}$ & - & - & - \\
\hline Swarna X ICSV 25019 & -0.33 & 1.17 & -1.11 & $0.20^{\star \star}$ & 0.05 & - & - & - \\
\hline Swarna X PS 35805 & -0.33 & -0.33 & -5.00 & 0.08 & -0.12 & - & - & - \\
\hline Swarna X IS 2123 & $1.70^{*}$ & $2.17^{\star}$ & $10.56^{* \star}$ & 0.15 & -0.07 & 0.17 & - & 0.17 \\
\hline Swarna X IS 2146 & 0.33 & 1.00 & -0.55 & 0.02 & 0.18 & $-0.30^{*}$ & - & - \\
\hline Swarna X IS 18551 & $1.80^{*}$ & -1.17 & -3.89 & 0.03 & 0.05 & - & - & - \\
\hline
\end{tabular}

*, **t-test significant at 0.05 and 0.01 probability levels; ORS, overall resistance score; $R$, rainy season; PR, postrainy season.

ICSV $25019 \mathrm{X}$ Phule Anuradha in the rainy season and Phule Anuradha X ICSV 700, CSV 15 X M 35-1, Swarna X CSV 15 in the postrainy season, and Swarna X M 35-1 across seasons, exhibited significant negative reciprocal effects for 100 seed weight. IS 2146 X ICSV 25019, Swarna X CSV 15, Swarna X ICSV 25019 in the rainy season and ICSV 25019 X CSV 15, PS 35805 X CSV 15 
in the postrainy season exhibited significant positive reciprocal effects for 100 seed weight.

\section{Combining Ability Estimates and Genetic Parameters}

Variance due to GCA $\left(\sigma^{2} \mathrm{~g}\right)$ was higher than the variance due to SCA $\left(\sigma^{2} s\right)$ for glume cover across seasons (Table 11); agronomic score and waxy bloom in the rainy season and days to $50 \%$ flowering and inflorescence exsertion in the postrainy season also showed high $g c a$ variance, indicating the predominance of additive gene action in controlling the expression of these traits. Plant height and grain yield exhibited higher $\sigma^{2} \mathrm{~s}$ than the $\sigma^{2} \mathrm{~g}$ across seasons; days to $50 \%$ flowering and inflorescence exsertion in the rainy season, and panicle shape in the postrainy season showed high $\sigma^{2} \mathrm{~s}$ than the variance due to $g c a$, indicating the predominance of non-additive type of gene action in controlling the expression of these traits. The other traits that had similar $\sigma^{2}$ $\mathrm{g}$ and $\sigma^{2} \mathrm{~s}$ exhibited both additive and non-additive type of gene action.

Glume cover showed greater additive $\left(\sigma^{2}\right.$ a) than the dominance variance $\left(\sigma^{2} d\right)$ across seasons. Agronomic score, waxy bloom, and panicle compactness in the rainy season, and days to $50 \%$ flowering, plant height, 100 seed weight, and inflorescence exsertion in the postrainy season showed higher additive variance than the dominance variance. Overall resistance score, grain yield, and plant color exhibited higher dominance variance than the additive variance across seasons. Days to $50 \%$ flowering, plant height, and inflorescence exsertion in the rainy season and panicle shape in the postrainy season possessed higher dominance variance than the additive variance.

Glume cover and awns exhibited high GCA/SCA ratios across seasons. Agronomic score, waxy bloom, and panicle compactness in the rainy season, and days to $50 \%$ flowering, plant height, 100 seed weight, and inflorescence exsertion in the postrainy season exhibited high GCA/SCA ratios, indicating the additive type of gene action controlling the expression of these traits. Panicle compactness, glume cover, and awns showed high predictability ratios across seasons. The predictability ratios for agronomic score, and waxy bloom in the rainy season, and days to $50 \%$ flowering, plant height, 100 seed weight, and inflorescence exsertion in the postrainy season were quite high. Heritability estimates of the traits studied ranged from 0.10 to 0.71 (narrowsense heritability), and 0.85 to 1.00 (broad-sense heritability) in the rainy season, and 0.17 to 0.82 (narrow-sense heritability), and 0.67 to 0.99 (broad-sense heritability) in the postrainy season. Almost all the traits exhibited moderate to high heritability values, except grain yield and grain luster across the seasons. Panicle shape in the postrainy season exhibited low $(\leq 0.30)$ narrow-sense heritability.

\section{DISCUSSION}

Significance of $F$-values for all the traits studied indicated the presence of high variability in the parents used for developing the full diallel. Plant height, 100 seed weight and grain yield were associated with susceptibility to shoot fly. Days to $50 \%$ flowering, agronomic score, inflorescence exsertion, panicle compactness, panicle shape, glume coverage, and awns were associated with shoot fly resistance.

Association between the shoot fly resistance, morphological, and agronomic traits suggested complex interactions between shoot fly and plant traits. Significance of the GCA and SCA mean sum of squares for all the traits across seasons suggested that both the additive and non-additive nature of gene action for agronomic and panicle characteristics. The significance of reciprocal combining ability effects for days to $50 \%$ flowering, plant height, and 100 seed weight, suggesting possible role of cytoplasmic factors in inheritance of these traits. These interactions should be taken into consideration while developing strategies for improving sorghums for shoot fly resistance and high grain yield.

Genotypes with negative GCA effects for days to 50\% flowering can be utilized to develop the hybrids with early flowering. To develop hybrids with moderate height, care should be taken to select the parents with moderate plant height. Additive gene action in the rainy season and dominance in the postrainy season for days to $50 \%$ flowering and plant height suggested G X E interactions for these traits. This contrasting gene expression in the rainy and postrainy seasons for days to $50 \%$ flowering and plant height suggested the season specific breeding of these traits for sorghum improvement. Meng et al. (1998), Rafiq et al. (2002), and Mohammed Maarouf (2009) reported additive gene action for days to $50 \%$ flowering, while Erenso (1998) reported additive gene action for plant height. Higher magnitude of SCA variance was reported by Manickam and Vijendra Das (1994) and Umakanth et al. (2002) for both the plant traits. High GCA/SCA and predictability ratios for 100 seed weight in the postrainy season indicated the predominance of additive gene action, whereas both additive and non-additive gene action was observed in the rainy season. Grain yield exhibited higher SCA variance suggesting the predominance of dominance (non-additive) type of gene action (Wilson et al., 1978; Singhania, 1980; Amsalu, 1987; Hovny et al., 2000; Umakanth et al., 2002; Girma et al., 2010). However, the importance of both the additive and non-additive gene action was observed for 100 seed weight by Toure et al. (1996).

Knowledge of the genetic architecture of grain yield, and morphological and agronomic traits will be useful for formulating a meaningful breeding strategy for developing improved genotypes. Genetic diversification of sorghum for key traits is important for sustaining the yield gains and mapping QTL underlying agronomically important traits is a key step in understanding their genetic control and for using the tightly linked markers for marker-assisted breeding for crop improvement (Srinivas et al., 2009; Ashok Kumar et al., 2011; Nagaraja Reddy et al., 2013, 2014). Many studies were conducted in identifying the QTL regions of different traits associated with insect resistance as well as the morphological and agronomic traits (Satish et al., 2009; Srinivas et al., 2009; Aruna et al., 2011b; Nagaraja Reddy et al., 2013, 2014). Based on the present inheritance studies of the agronomic and morphological traits and as well as the QTL information available one can effectively plan suitable breeding strategies for sorghum improvement. 
TABLE 11 | Estimates of various genetic parameters for different agronomic and panicle traits of sorghum across seasons (ICRISAT, Patancheru, 2013-14).

\begin{tabular}{|c|c|c|c|c|c|c|c|c|c|c|c|}
\hline Traits & $\begin{array}{l}\text { Days to } 50 \% \\
\text { flowering }\end{array}$ & $\begin{array}{l}\text { Plant height } \\
\text { (cm) }\end{array}$ & $\begin{array}{c}100 \text { seed } \\
\text { weight }(g)\end{array}$ & $\begin{array}{c}\text { Grain yield } \\
\text { (t/ha) }\end{array}$ & $\begin{array}{l}\text { Agronomic } \\
\text { score }\end{array}$ & $\begin{array}{c}\text { Inflorescence } \\
\text { exsertion }\end{array}$ & $\begin{array}{c}\text { Panicle } \\
\text { compactness }\end{array}$ & $\begin{array}{l}\text { Panicle } \\
\text { shape }\end{array}$ & $\begin{array}{c}\text { Glume } \\
\text { coverage }\end{array}$ & Awns & $\begin{array}{l}\text { Grain } \\
\text { lustre }\end{array}$ \\
\hline \multirow[t]{2}{*}{$\sigma^{2} g$} & 3.70 & 730.03 & 0.04 & 0.57 & 0.34 & 0.10 & 0.08 & $(0.24)$ & 0.87 & 0.10 & - \\
\hline & (8.31) & (285.66) & $(0.10)$ & $(2.17)$ & $(0.15)$ & $(0.54)$ & (0.09) & & 0.87 & 0.10 & \\
\hline \multirow[t]{2}{*}{$\sigma^{2} s$} & 9.05 & 1817.89 & 0.08 & 3.44 & 0.32 & 0.27 & 0.07 & $(1.27)$ & 0.51 & 0.12 & 0.02 \\
\hline & (6.44) & (460.32) & (0.16) & $(11.87)$ & & (0.49) & $(0.16)$ & & (0.38) & $(0.12)$ & $(0.01)$ \\
\hline$\sigma^{2} r$ & $0.74(1.48)$ & $(17.53)$ & $(0.02)$ & - & - & 0.03 & $(0.01)$ & $(0.1)$ & - & - & - \\
\hline \multirow[t]{2}{*}{$\sigma^{2} e$} & 1.27 & 38.62 & 0.02 & 0.50 & 0.12 & 0.06 & 0.01 & $(0.13)$ & 0.19 & - & - \\
\hline & (1.96) & (33.99) & (0.02) & (1.08) & $(0.16)$ & (0.09) & (0.01) & & $(0.11)$ & & \\
\hline \multirow[t]{2}{*}{$\sigma^{2} a$} & 7.40 & 1460.07 & 0.08 & 1.13 & 0.67 & 0.21 & 0.17 & $(0.48)$ & 1.74 & 0.19 & - \\
\hline & (16.62) & (571.32) & $(0.20)$ & $(4.34)$ & (0.29) & $(1.07)$ & $(0.17)$ & & $(2.10)$ & $(0.19)$ & \\
\hline \multirow[t]{2}{*}{$\sigma^{2} d$} & 9.05 & 1817.89 & 0.08 & 3.44 & 0.32 & 0.27 & 0.07 & $(1.27)$ & 0.51 & 0.12 & 0.02 \\
\hline & $(6.44)$ & (460.32) & $(0.16)$ & $(11.87)$ & & $(0.49)$ & $(0.16)$ & & $(0.38)$ & $(0.12)$ & $(0.01)$ \\
\hline \multirow[t]{2}{*}{$\sigma^{2} p$} & 18.45 & 3317.39 & 0.18 & 5.17 & 1.14 & 0.57 & 0.25 & $(1.97)$ & 2.46 & 0.32 & 0.02 \\
\hline & $(26.50)$ & (1083.15) & $(0.40)$ & (17.29) & $(0.41)$ & (1.66) & (0.35) & & (2.55) & $(0.31)$ & (0.02) \\
\hline \multirow[t]{2}{*}{$h_{n s^{2}}$} & 0.40 & 0.44 & 0.45 & 0.22 & 0.59 & 0.37 & 0.68 & $(0.24)$ & 0.71 & 0.60 & 0.10 \\
\hline & (0.63) & (0.53) & $(0.51)$ & $(0.25)$ & $(0.71)$ & (0.65) & $(0.50)$ & & $(0.82)$ & $(0.60)$ & $(0.17)$ \\
\hline \multirow[t]{2}{*}{$h_{b}{ }^{2}$} & 0.89 & 0.99 & 0.90 & 0.88 & 0.87 & 0.85 & 0.95 & (0.89) & 0.92 & 1.00 & 1.00 \\
\hline & $(0.87)$ & $(0.95)$ & (0.91) & (0.94) & (0.67) & (0.94) & (0.94) & & $(0.97)$ & (0.99) & $(0.78)$ \\
\hline \multirow[t]{2}{*}{ GCA/SCA ratio } & 0.41 & 0.40 & 0.49 & 0.16 & 1.04 & 0.38 & 1.26 & $(0.19)$ & 1.70 & 0.77 & 0.06 \\
\hline & (1.29) & (0.62) & $(0.64)$ & (0.18) & & (1.09) & $(0.55)$ & & (2.73) & $(0.75)$ & $(0.14)$ \\
\hline \multirow[t]{2}{*}{ Predictability ratio } & 0.45 & 0.45 & 0.5 & 0.25 & 0.68 & 0.43 & 0.72 & $(0.27)$ & 0.77 & 0.61 & 0.10 \\
\hline & $(0.72)$ & $(0.55)$ & $(0.56)$ & $(0.27)$ & & (0.69) & (0.53) & & $(0.85)$ & $(0.6)$ & $(0.22)$ \\
\hline
\end{tabular}

$\sigma^{2} g$, gca variance; $\sigma^{2} s$, sca variance; $\sigma^{2} r$, reciprocal variance; $\sigma^{2} e$, environmental/error variance; $\sigma^{2} a$, additive variance; $\sigma^{2} d$, dominance variance; $\sigma^{2} p$, phenotypic variance; $h_{n s^{2}}$,

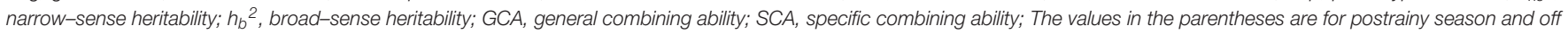
the parentheses are for rainy season.

Most of the hybrids studied exhibited higher grain yield than the parents even if one of the parent was high yielding, suggesting that one of the parent should possess high grain yield ability for developing high yielding hybrids. This is very critical in sorghum improvement considering the fact that hybrids are preferred over the varieties worldover, barring Africa. Most of the commercial hybrids show $30-40 \%$ yield superiority over the best varieties in a given ecology. The panicle trait such as inflorescence exsertion exhibited predominance of additive gene action in the postrainy season, and dominance gene action in the rainy season, while glume cover and presence of awns showed predominance of additive gene action.

The genotypes CSV 15, ICSV 25019, PS 35805, and Swarna exhibited negative gca effects for almost all the traits, but positive $g c a$ effects for grain yield. Hence, these genotypes can be effectively used in breeding the high yielding sorghums. The crosses involving the genotype IS 2146 either as male or female parent showed a decrease in grain yield being a poor combiner coupled with low per se mean yield. Phule Anuradha and M 35-1 showed positive gca effects for 100 seed weight but negative $g c a$ effects for grain yield in the rainy season, and positive effects in the postrainy season, suggesting that these genotypes can be effectively utilized for breeding high yielding shoot fly resistant sorghums for the postrainy season. Both M 35-1 and Phule Anuradha are highly adapted to postrainy environments, and are very popular with farmers. ICSV 25019, PS 35805, IS 2123, and IS 18551 exhibited negative gca effects for 100 seed weight, but showed positive gca effects for grain yield. Hence, these genotypes can be utilized for breeding high yielding sorghums with shoot fly resistance. Though the genotypes CSV 15 and Swarna showed positive gca effects for 100 seed weight and grain yield, but these may not be good parents in a shoot fly resistance breeding program. ICSV 700, IS 2123, and IS 18551 showed positive gca effects for most of the traits and these can be utilized for improving shoot fly resistance. Higher narrow- and broad-sense heritability estimates suggested high heritability of these traits across environments, and greater role of additive gene action, suggesting that selection is effective for improving these traits. This information can be used for developing high yielding cultivars with insect resistance for sustainable crop production.

\section{CONCLUSIONS}

Genotypic response varies across seasons, and hence, it is important to identify genotypes with desirable agronomic traits, insect resistance, and high grain yield for different seasons and locations. The genotypes ICSV 700, Phule Anuradha, M 35-1, ICSV 25019, PS 35805, IS 2123, and IS 18551 exhibiting moderate to high shoot fly resistance and desirable agronomic traits, can be effectively used in sorghum improvement. Both additive and non-additive type of gene action governs the morphological (inflorescence exsertion, panicle compactness, and panicle shape) and agronomic (days to 50\% flowering, plant height and 100 seed weight) traits and hence it is important to exploit heterosis breeding for improving agronomic and morphological traits and grain yield in sorghum. The significance of reciprocal effects for some of the traits (days to $50 \%$ flowering, plant height, and 100 seed weight) suggested that apart from the direct genetic 
effects, the cytoplasmic factors also played an important role in inheritance of these traits. An understanding of the association between shoot fly resistance and morphological and agronomic traits will be useful to improve the strategies to develop shoot flyresistant cultivars with desirable plant types, and season specific adaptation for sustainable crop production.

\section{ACKNOWLEDGMENTS}

We are thankful to the sorghum entomology and breeding staff for their help in carrying out the field experiments, and

\section{REFERENCES}

Amsalu, A. (1987). Heterosis and Combining Ability Studies in Grain Sorghum [Sorghum bicolour (L.) Moench]. M.Sc. thesis, Mahatma Phule Agricultural University, Maharashtra.

Aruna, C., Bhagwat, V. R., Madhusudhana, R., Vittal, S., Hussain, T., Ghorade, R. B., et al. (2011b). Identification and validation of genomic regions that affect shoot fly resistance in sorghum [Sorghum bicolor (L.) Moench]. Theor. Appl. Genet. 122, 1617-1630. doi: 10.1007/s00122-011-1559-y

Aruna, C., Bhagwat, V. R., Vittal, S., Hussain, T., Ghorade, R. B., Khandalkar, H. G., et al. (2011a). Genotype X Environment interactions for shoot fly resistance in sorghum [Sorghum bicolor (L.) Moench]: response of recombinant inbred lines. Crop Prot. 30, 623-630. doi: 10.1016/j.cropro.2011.02.007

Ashok Kumar, A., Reddy, B. V. S., Sharma, H. C., Hash, C. T., Srinivasa Rao, P., Ramaiah, B. et al. (2011). Recent advances in sorghum genetic enhancement research at ICRISAT. Am. J. Plant Sci. 2, 589-600. doi: 10.4236/ajps.2011.24070

Baker, R. J. (1978). Issues in diallel analysis. Crop Sci. 18, 533-536. doi: 10.2135/cropsci1978.0011183X001800040001x

Melake-Berhan, A, Butler, L. G., Ejeta, G., and Menkir, A. (1996). Grain mold resistance and polyphenol accumualation in sorghum. J. Agr. Food Chem. 44, 2428-2434. doi: 10.1021/jf950580x

Dhillon, M. K., Sharma, H. C., Folkertsama, R. T., and Chandra, S. (2006). Genetic divergence and molecular characterisation of sorghum hybrids and their parents for reaction to Atherigona soccata (Rondani). Euphytica 149, 199-210. doi: 10.1007/s10681-005-9067-2

Erenso, D. (1998). Study of Combining Ability in Lowland Grain Sorghum [Sorghum bicolor (L.) Moench]. M.Sc. thesis, Alemaya University, Ethiopia.

FAO (2004). Production Yearbook. Rome: FAO.

FAOSTAT (2012). Crops Primary Equivalent. Available online at: http://faostat.fao. org. (Retrieved 15th March, 2015).

GenStat (2010). Introduction to GenStat for Windows Genstat, 13th Edn. Harpenden: Lawes Agricultural Trust, Rothamsted Experimental Station.

Girma, M., Amsalu, A., and Ketema, B. (2010). Combining ability for yield and its components in ethiopian sorghum [Sorghum bicolor (L.) Moench] landraces. East Afr. J. Sci. 4, 34-40. doi: 10.4314/eajsci.v4i1.71522

Griffing, B. (1956). Concept of general and specific combining ability in relation to diallel crossing systems. Aust. J. Biol. Sci. 9, 463-493.

Hovny, M. R. A., El-Naggouly, O. O., and Hassaballa, E. A. (2000). Combining ability and heterosis in grain sorghum [Sorghum bicolor (L.) Moench]. Assiut J. Agr. Sci. 31, 1-16.

IBPGR and ICRISAT (1993). Descriptors for Sorghum [Sorghum bicolor (L.) Moench]. International Board for Plant Genetic Resources. Rome: International Crops Research Institute for the Semi-Arid Tropics (ICRISAT), Patancheru.

Indostat Services (2004). Windostat. Hyderabad: Indostat Services.

Jayanthi, P. D. K., Reddy, B. V. S., Reddy, D. D. R., Gour, T. B., and Nwanze, K. F. (1996). "Genetics of shoot fly resistance in sorghum hybrids of cytoplasmic male sterile lines," in Abstracts of Poster Sessions: 2nd International Crop Science Congress: Crop Productivity and Sustainability -Shaping the Future (New Delhi: National Academy of Agricultural Sciences, Indian Council of Agricultural Research), 152.
Bill \& Melinda Gates Foundation for financial support through HOPE-Sorghum and Millets project. We also thank, Dr. P. Janila for reviewing and providing constructive suggestions on this manuscript.

\section{SUPPLEMENTARY MATERIAL}

The Supplementary Material for this article can be found online at: http://journal.frontiersin.org/article/10.3389/fpls.2015. 00945
Johnson, H. W., Robinson, H. F., and Comstock, R. E. (1955). Estimates of genetic and environmental variability in soybean. Agron. J. 47, 314-318. doi: 10.2134/agronj1955.00021962004700070009x

Kullaiswamy, B. Y., and Goud, J. V. (1983). New genes for awning in sorghum [Sorghum bicolor (L.) Moench]. Madras Agr. J. 70, 355-359.

Manickam, S., and Vijendra Das, L. D. (1994). Line X tester analysis in forage sorghum. Int. Sorghum Millet Newslett. 35, 79-80.

Meng, C. G., An, X. M., Zhang, F. Y., Zheng, J. B., Wang, L. X., and Li, P. L. (1998). Analysis of combining ability of newly developed sorghum male sterile lines. Acta Agr. Boreali-Sinica 13, 81-85.

Mohammed Maarouf, I. (2009). Line X tester analysis across locations and years in Sudanese $\mathrm{x}$ exotic lines of forage sorghum. J. Plant Breed. Crop Sci. 1, 311-319. Available online at: http://www.academicjournals.org/article/ article1379424511_Mohammed.pdf

Murty, D. S. (2000). "Breeding for grain mold resistance in sorghum: opportunities and limitations," in Technical and Institutional Options for Sorghum Grain Mold Management: Proceedings of an International Consultation, 18-19 May 2000, eds A. Chandrashekar, R. Bandyopadhyay and A. J. Hall (Patancheru: International Crops Research Institute for the Semi-Arid Tropics (ICRISAT)), 225-227.

Nagaraja Reddy, R., Madhusudhana, R., Murali Mohan, S., Chakravarthi, D. V. N., Mehtre, S. P., Seetharama, N., et al. (2013). Mapping QTL for grain yield and other agronomic traits in post-rainy sorghum [Sorghum bicolor (L.) Moench]. Theor. Appl. Genet. 126, 1921-1939. doi: 10.1007/s00122-013-2107-8

Nagaraja Reddy, R., Madhusudhana, R., Murali Mohan, S., Seetharama, N., and Jagannatha Vishnu, P. (2014). Detection and validation of stay-green QTL in post-rainy sorghum involving widely adapted cultivar, M35-1 and a popular stay-green genotype B35. BMC Genomics 15:909. doi: 10.1186/1471-216415-909

Nimbalkar, V. S., and Bapat, D. R. (1992). Inheritance of shoot fly resistance in sorghum. J. Maharashtra Agric. Univ. 17, 93-96.

Porter, K. S., Axtell, J. D., Lechtenberg, V. L., and Colenbrander, V. F. (1978). Phenotype, fiber composition, and in vitro dry matter disappearance of chemically induced brown midrib (bmr) mutants of sorghum. Crop Sci. 18, 205-208. doi: 10.2135/cropsci1978.0011183X001800020002x

Rafiq, S. M., Thete, R. Y., Madhusudhana, R., and Umakanth, A. U. (2002). Combining ability studies for grain yield and its components in postrainy season sorghum grown in medium-deep and shallow soils. Int. Sorghum Millets Newslett. 43, 33-37. Available online at: http://oar.icrisat.org/1106/1/ RA_00378.pdf

Riyazaddin, M. D., Kavi Kishor, P. B., Ashok Kumar, A., Belum Reddy, V. S., Rajendra, S. M., and Sharma, H. C. (2015). Mechanisms and diversity of resistance to sorghum shoot fly, Atherigona soccata. Plant Breed. 134, 423-436. doi: $10.1111 /$ pbr. 12276

Satish, K., Srinivas, G., Madhusudhana, R., Padmaja, P. G., Nagaraja Reddy, R., Murali Mohan, S., et al. (2009). Identification of quantitative trait loci for resistance to shoot fly in sorghum [Sorghum bicolor (L.) Moench]. Theor. Appl. Genet. 119, 1425-1439. doi: 10.1007/s00122-009-1145-8

Sharma, H. C. (1993). Host-Plant Resistance to insects in sorghum and its role in integrated pest management. Crop Prot. 12, 11-34. doi: 10.1016/02612194(93)90015-B 
Sharma, H. C., Reddy, B. V. S., Dhillon, M. K., Venkateswaran, K., Singh, B. U., Pampapathy, G., et al. (2005). Host plant resistance to insects in sorghum: present status and need for future research. Int. Sorghum Millets Newslett. 46, 36-43. Available online at: http://oar.icrisat.org/1215/1/ISMN-46_36-43_2005. pdf

Sharma, H. C., Taneja, S. L., Kameswara Rao, N., and Prasada Rao, K. E. (2003). Evaluation of Sorghum Germplasm for Resistance to Insect Pests. Information Bulletin no. 63. Patancheru: International Crops Research Institute for the Semi-Arid Tropics (ICRISAT).

Singhania, D. L. (1980). Heterosis and combining ability studies in grain sorghum. Indian J. Genet. 40, 463-471.

Srinivas, G., Satish, K., Madhusudhana, R., Nagaraja Reddy, R., Murali Mohan, S., and Seetharama, N. (2009). Identification of quantitative trait loci for agronomically important traits and their association with genic-microsatellite markers in sorghum. Theor. Appl. Genet. 118, 1439-1454. doi: 10.1007/s00122009-0993-6

Toure, A., Miller, F. R., and Rosenow, D. T. (1996). Heterosis and combining ability for grain yield and yield components in guinea sorghums. J. Afr. Crop Sci. 4, 383-391.
Umakanth, A. V., Madhusudhana, K., Madhavi Latha, P., Hema, K., and Kaul, S. (2002). Genetic architecture of yield and its contributing characters in postrainy season sorghum. Int. Sorghum Millets Newslett. 43, 37-40. Available online at: http://oar.icrisat.org/1106/1/RA_00378.pdf

Wilson, N. D., Weibel, D. E., and McNew, R. W. (1978). Diallel analyses of grain yield, percent protein, and protein yield in grain sorghum. Crop Sci. 18, 491-495.

Conflict of Interest Statement: The authors declare that the research was conducted in the absence of any commercial or financial relationships that could be construed as a potential conflict of interest.

Copyright (C) 2015 Mohammed, Are, Bhavanasi, Munghate, Kavi Kishor and Sharma. This is an open-access article distributed under the terms of the Creative Commons Attribution License (CC BY). The use, distribution or reproduction in other forums is permitted, provided the original author(s) or licensor are credited and that the original publication in this journal is cited, in accordance with accepted academic practice. No use, distribution or reproduction is permitted which does not comply with these terms. 